\title{
Phillips Curve Is a Particular Case that Economists Misinterpret the Correlation between Two Dependent Variables for Causal Relation
}

\author{
Chao Chiung Ting ${ }^{1}$ \\ ${ }^{1}$ Graduated from Michigan State University, USA \\ Correspondence: Chao Chiung Ting, Graduated from Michigan State University, 6333 98th Place 1E, Rego Park, \\ NY 11374, USA. E-mail: tingtch7ti@aol.com
}

Received: September 5, 2018

doi:10.5539/ijef.v10n11p70

\author{
Accepted: October 18, $2018 \quad$ Online Published: October 25, 2018 \\ URL: https://doi.org/10.5539/ijef.v10n11p70
}

\begin{abstract}
Since labor supply and labor demand determines both employment and wage in labor market endogenously, both wage and employment, which we observe, are dependent variable in the sense of ex-post. Since unemployment is equal to labor supply minus labor demand, unemployment is dependent variable in the sense of ex-post, too. There is no causal relation between two dependent variables because independent variable explains dependent variable. Thus, the relationship between ex-post unemployment and ex-post wage in Phillips (1958) is not causal relation but correlation as meaningless as the strong correlation between ice cream sale and drowning rate. Similarly, both price and quantity we observe are determined by supply and demand endogenously in the sense of ex-post. Thus, inflation rate is dependent variable because inflation rate is the change in price level (i.e., change in the average price of all goods in the sense of ex-post). Hence, we are not permitted to explain unemployment rate by inflation rate and vice versa. As Friedman (1977) conjectured that Phillips curve is correlation which is misinterpreted for causal relation (i.e., trade-off) by economists, I conclude that Phillips curve is meaningless correlation between two dependent variables so that economic policy based on Phillips curve is invalid.

Keywords: Phillips Curve, trade-off, natural rate unemployment, involuntary unemployment, income effect, output effect, substitution effect, independent variable, dependent variable, correlation, causality, neutrality of money, keynesian unemployment equilibrium, econometric policy evaluation
\end{abstract}

\section{Introduction}

\subsection{The Debate on Causality versus Correlation of Phillips Curve: Brief Review}

Phillips (1958) found significantly negative correlation between unemployment rate and nominal wage rate in British. Although Phillips curve is statistical structure instead of theoretical framework in macroeconomics, Phillips curve is influential for two reasons. First, Phillips curve is opposite to the positive relationship between unemployment and wage implied by labor demand curve so that the analysis of labor supply and labor demand in microeconomics seems to be not able to explain Phillips curve. Thus, Phillips curve demonstrates the irrelevance between macroeconomics and microeconomics. Second, economists interpreted Phillips curve as trade-off so that economists count on statistics to propose economic policy because empirical approach and theoretical approach are supposed to reach the same result even economists are not be able to explain statistical structures by economic theory. Consequently, economists have devoted themselves to discovering new statistical structures in the sense of macroeconomics (e.g., Okun gap and real business cycle) instead of advancing economic theory since then.

Samuelson and Solow (1960) studied the relationship between inflation rate and unemployment rate instead of the relationship between nominal wage rate and unemployment rate in Phillips (1958) because Samuelson and Solow recognized the close linkage between wage and inflation based on cost-push inflation (i.e., rise in wage pushes product prices upward) and demand-pull inflation (i.e., increase in demand pulls both product prices and wage upward). Thereafter, I name the Phillips curve in Phillip (1958) to be wage Phillips curve and the Phillips curve in Samuelson and Solow (1960) to be inflation Phillips curve. When I write Phillips curve in this paper below, I refer to both wage Phillips curve and inflation Phillips curve.

Samuelson and Solow (1960, p. 193) wrote "All of our discussion has been phrased in short-run terms, dealing 
with what might happen in the next few years. It would be wrong, though, to think that our Figure 2 menu that relates obtainable price and unemployment behavior will maintains same shape in the longer run. What we do in policy way during the next few years might cause it to shift in a definite way." Obviously, Samuelson and Solow believed that trade-off between inflation rate and unemployment rate is stable in the short run but unstable in the long run because economic agents will automatically change their behavior in order to respond to the change in economic policy by which government exploits trade-off.

Unlike Samuelson and Solow who did not formally provide a model to explain why inflation Phillips curve shifts in the long run but the stable trade-off works in the short run. Friedman not only absolutely denied the trade-off between unemployment rate and inflation rate in the short run and long run but also provided natural rate unemployment hypothesis to explain why Phillips curve shifts in the long run. Friedman (1977) stated "this correlation was widely interpreted as a causal relation that offered a stable trade-off to policy makers". Comparing with Friedman $(1974$, p. 5), Friedman wrote "The boom that typically accompanies the onset of accelerated inflation is not the cause of the inflation but a side effect. The recession and unemployment that typically accompany the reduction of inflation are not the cure but a side effect." Since boom and recession regard total quantity of output produced currently in terms of GDP and price level is the index indicating change in the average price of current outputs while the change in price level is named to be inflation rate by economists, inflation rate is the "price" (nominal factor) corresponds to total quantity of current output (real factor). Excess demand implies that rise in price (e.g., rise in wage and inflation rate) accompanies rise in quantity (e.g., rise in employment and GDP) in boom because supply and demand, which are cause and independent variable, determines not only price but also quantity, which are effect and dependent variable, simultaneously. Thus, rise in employment and GDP does not cause inflation but statistically associates with inflation in the sense of correlation. Conversely, excess supply suggests that deflation statistically accompanies fall in employment and GDP so that fall in employment and GDP is side effect of deflation in the sense of correlation, not cure of inflation. Friedman (1974) implied that it is a false idea that price determines quantity and vice versa. Note that unemployment is also dependent variable determined by supply of labor and demand for labor endogenously because unemployment is the difference between labor supply and labor demand. We are not allowed to explain ex-post price by ex-post quantity and vice versa although there is correlation between two dependent variables (e.g., unemployment rate explains inflation rate as inflation Phillips curve does) because independent variable explains dependent variable absolutely. Thus, the absolute denial of causal relation between inflation rate and unemployment rate in Friedman $(1974,1977)$ is consistent with the analysis of supply and demand in microeconomics whether Friedman referred to short run or long run.

Further, Friedman (1970) declared "Inflation is always and everywhere a monetary phenomenon in the sense that it is and can be produced only by a more rapid increase in the quantity of money ..." Friedman explained inflation rate by money growth rate based on quantity theory of money. Thus, unemployment rate does not influence on inflation rate absolutely. Since quantity theory of money predicts neutrality of money in the long run, inflation rate does not affect unemployment rate in the long run. Hence, Friedman (1970) is consistent with Friedman $(1974,1977)$ when we take Friedman's theoretical framework as a whole. I conclude that Friedman is different from Samuelson and Solow because Friedman argued that there is neither short run causal relation nor long run causal relation between unemployment rate and inflation rate absolutely (i.e., no trade-off under any circumstance) while Samuelson and Solow believed that trade-off is always valid but unstable in the long term.

Although Friedman used natural rate unemployment hypothesis to explain why short run inflation Phillips curve shifts, Friedman did not recognize that shifting in short run inflation Phillips curve does not prove that the slope of Phillips curve is not causal relation but correlation. Let $y=a+b x$ be regression. Since causality usually refers to the relationship between variable $x$ and variable $y$, causal relation between variable $x$ and variable $y$ is represented by the stability of coefficient $b$. Coefficient $b$ is variant because either there is no causal ration between variable $x$ and variable $y$ or there are other variables which affect variable $y$ (e.g., $y=a+b x+c z$ is the true specification). Similarly, the change in coefficient $a$ means that this regression shifts due to the reason that either there are variables to affect variable $y$ in addition to variable $x$ or there is no causal relation between variable $x$ and variable $y$. Otherwise, coefficient $a$ will not change. Shifting in short run Phillips curve corresponds to the change in interception of a regression but the numerical value of coefficient $b$ and the sign of coefficient $b$ are not necessary to change. For example, change in income shifts demand curve but shifting in demand curve does not disprove the negative relationship between price and quantity on demand curve estimated by us. Thus, it is wrong that there is no negative relationship between price and quantity on short run demand curve because long run demand curve is vertical. I conclude that Friedman's ineffectiveness of trade-off in the long run does not prove that the slope of short run inflation Phillips curve is not causal relation 
but correlation. Besides, Friedman (1968, p. 8) wrote “...there is always a temporary trade-off between inflation and unemployment; there is no permanent trade-off. The temporary trade-off comes not from inflation per se, but from unanticipated inflation..." Natural rate unemployment hypothesis in Friedman (1968) is contrary to Friedman $(1974,1977)$ because the temporary trade-off is the causal relation between unemployment rate and unanticipated inflation rate in Friedman (1968) but there is no causal relation between inflation rate and unemployment rate in Friedman $(1974,1977)$ whether inflation rate refers to anticipated inflation rate or unanticipated inflation rate.

Let $x=c+d\left(p-p^{e}\right)$ be Friedman's inflation Phillips curve based on natural rate unemployment hypothesis, where $c, x, p^{e}$ and $p$ are natural rate of unemployment, actual unemployment rate, anticipated inflation rate and actual inflation rate. Since actual inflation rate is equal to unanticipated inflation rate plus anticipated inflation rate, $p-p^{e}$ is equivalent to unanticipated inflation rate. Let's study a case. Assume that natural rate of unemployment is 4 percent, actual inflation rate is higher than anticipated inflation rate by 1 percent (i.e., unanticipated inflation rate is 1 percent) and coefficient $d$ is equal to -1 because the slope of inflation Phillips curve is negative. In this case, actual unemployment rate is equal to 3 percent. Under natural rate unemployment hypothesis, the inflation Phillips curve of Samuel and Solow is equivalent to $p=\frac{c-d p^{e}}{d}+\frac{x}{d}$. Inflation Phillips curve shifts because anticipated inflation rate makes interception be variant. Since $d$ is stable, $d$ represents cause. Thus, empirical study is not able to statistically reject the causal relation between actual employment rate and actual inflation rate even natural rate unemployment hypothesis is true because actual inflation rate is the sum of anticipated inflation rate and unanticipated inflation rate (i.e., unanticipated inflation rate is an element contained by actual inflation rate) while unanticipated inflation affects actual unemployment. Thus, actual inflation rate impacts on actual unemployment rate absolutely in the sense of statistics although actual inflation rate is biased estimator to represent unanticipated inflation rate. In other words, the vertical long run inflation Phillips curve is not the disproof of causal relation between actual inflation rate and actual unemployment rate (i.e., trade-off) but many on one mapping between actual inflation rate and unemployment rate mathematically due to changes in coefficient $a$.

It is worth noting that Granger and Jeon (2009) stated that wage rate is effect while unemployment rate is cause in Phillips (1958). But natural rate unemployment hypothesis suggested that unanticipated inflation rate is cause and actual unemployment rate is effect in Friedman (1968). Concerning the relationship between price (nominal factor) and quantity (real factor), Friedman (1968) and Phillips (1958) are contrary to each other. It leads me to discuss what the true relationship between price and quantity is in section 3 .

Certainly, correlation does not imply causality. For example, there is strong and stable correlation between ice cream sale and drowning rate but ice cream sale is not the cause of drowning rate and vice versa. Since temperature is the common factor which affects both ice cream sale and drowning rate, the time series of ice cream sale and the time series of drowning rate assimilate like cointegration. Thus, there is strong and stable correlation between ice cream sale and drowning rate although there is no causal relation between ice cream sale and drowning rate. If there is no causal relation between two events, we should observe samples that the relationship between two events disclosed by a single sample is opposite to the relationship between two events demonstrated by correlation. For instance, the relationship of a single sample drawn from desert shows that ice cream sale is high but drowning rate is low although the correlation between ice cream sale and drowning rate based on global samples is positive. I review Phillips (1958) in which there were seven samples with positive relationship between unemployment rate and nominal wage rate (1861-2 and 1867-8 in figure 2, 1878-9 in figure 3, 1885-6 in figure 4, 1896-7 and 1903-4 in figure 6, and 1912-3 in figure 8). These seven samples of positive relationship between nominal wage rate and unemployment rate are empirical evidences to hint that wage Phillips curve would be a stable but meaningless correlation between nominal wage rate and unemployment rate rather than causal relation.

It is the key idea of this paper that the sign of coefficient $b$ in $y=a+b x$ will not change even regression is specified differently (e.g., $y=a+b x+c z$ ) if there is causal relation between variable $x$ and variable $y$. In other words, if there is no causal relation between variable $x$ and variable $y$, we should get both the positive 
coefficient $b$ and negative coefficient $b$ either under the same specification but different sample sets (e.g., samples of ice cream sale and drowning rate collected in desert) or under different specifications but the same sample set. For example, Teles and Zhou (2005) found that the correlation between interest rate and money demand was not only negative but also positive. The result of Teles and Zhou empirically implies that quantity theory of money is false due to missing causation mechanism between quantity of money and interest rate. It empirically supports the demonstration in Ting (2017a) that quantity theory of money is false because Fisher's exchange equation is derived from the definition of income velocity and there is neither causality nor logical inference in the definition of income velocity. Further, quantity of money is determined by money supply and money demand endogenously. Aggregate income is determined by demand for total current output and supply of total output endogenously. Interest rate is determined by supply of loan and demand for loan endogenously. Consequently, I interpret the meaning of Ting (2017a) as the theoretical proof that both the correlation between quantity of money and aggregate income and the correlation between quantity of money and interest rate are identical to the correlation between two dependent variables (e.g., Phillips curve), which is as meaningless as the correlation between ice cream sale and drowning rate from the view point of missing causation mechanism. As Phillips curve is unstable, Ting (2017a) predicted that both the correlation between money and aggregate income (i.e., income velocity) and the correlation between money and interest rate are unstable in the long term. Ting's prediction complies with the common sense in monetary economics that money demand (i.e., income velocity) has been unstable since Goldfeld (1976). To summarize, there is no causal relation (i.e., trade-off) between nominal wage rate and unemployment rate as well as inflation rate and unemployment rate empirically if we observe that the slope of Phillips curve is not only positive but also negative.

The slope of inflation Phillips curve during two oil crises (1973-1982) in U.S. was positive and Friedman (1977) admitted that natural rate of unemployment hypothesis cannot explain the positive slope inflation Phillips curve during two oil crises. Bhattari (2016) found that there is no evidence of trade-off in Austria, Germany, Israel and Norway as well as there are positive correlation between inflation and unemployment for Korea, Russia and Slovak Republic. Williamson (2015) reported that the slope of Phillips curve was positive in U.S. after Great Recession. Broadberry et.al (2012) found that Phillips curve was slightly positive from 1700 to 1870 and there was no Phillips curve between 1200 and 1700 in U.K. There was Tudor great inflation from 1500 to 1700 in U.K. while price level was almost fixed between 1300 and 1500. Friedman $(1968$, p. 8) wrote "Implicitly, Phillips wrote his article for a world in which everyone anticipated that nominal price would be stable and in which that anticipation remains unshaken and immutable whatever happen to actual prices and wages." Friedman's argument cannot explain why there was no Phillips curve when nominal price was stable between 1300 and 1500 in U.K. although Friedman's argument explains why there was no Phillips curve during Tudor great inflation.

Missing inflation and missing deflation suggests that inflation Phillips curve have become very flat since 1990s in U.S. It implies inflation Phillips curve would be horizontal (e.g., price rigidity recovery between 1934 and 1939 in U.S.) rather than vertical if there is no causation mechanism between inflation and unemployment. Thus, the hybrid New Keynesian Phillips curve is wrong because New Keynesian economics attributes flat Phillips curve to hysteresis of price expectation instead of non-causality. Besides, Borio et al. (2015) studied 38 economies covering 140 years and concluded that the relationship between inflation and unemployment was very weak and Guido and Eliana (2016) found that the wage Phillips curve became stepper in Euro area, which implies that there are factors influencing on wage in addition to unemployment.

Economists usually emphasized deflationary recession because of Great Depression. But inflationary recession also existed, e.g., oil crisis and hyperinflation in Germany 1923. In addition to post war inflationary growth, deflationary growth appeared in nineteenth century frequently. Rothbard (2002) investigated the deflationary growth between 1839 and 1843 in U.S. Neely (2010) reminded us that price level fell on average almost 5 percent per year from 1876 to 1879 in U.S. while average output growth exceeded 7.6 percent. Bordo et.al (2004) studied deflationary growth in U.S., British and Germany from 19th century to the First World War. From the view point of microeconomics, deflationary growth arises from cost down and technology progress (i.e., supply curve shifts rightward). For example, the price of computer and the price of smart phone decreased tremendously in recent decades while quantity of computer and smart phone also increased tremendously at the same era. Deflationary growth implies that the slope of inflation Phillips curve is positive because unemployment usually decreases when economy grows. Note that the hybrid New Keynesian Phillips curve neither complies with deflationary growth nor explains positive slope Phillips curve.

Since the relationship between price and quantity is random if both supply curve and demand curve shift, regression based on time series of price (e.g., wage) and quantity (e.g., unemployment) is not able to settle the debate on causality versus correlation of Phillips curve because some empirical studies will support trade-off 
while the other empirical studies will deny trade-off. Thus, economists asked alternative methods to test Phillips curve. Economists would count on Granger causality test to statistically identify the causal relation between unemployment rate and wage rate as well as unemployment rate and inflation rate rather than the sign of coefficient $b$. If we use Granger Causality test to study relationship between two dependent variables, bidirectional causality should be observed frequently in empirical studies because there is no causal relation between two dependent variables. For example, quantity of money and aggregate income are two dependent variables, which coexist simultaneously and pro-cyclically in the sense of ex-post, so that Sims (1972) found unidirectional causality from money to aggregate income but Thornton and Batten (1985) reported bidirectional Granger causality between quantity of money and aggregate income. Besides, bidirectional Granger causality implies circular reasoning because two variables explain each other.

Granger and Jeon (2009) found that causation is one way from unemployment to inflation but one way causation is weak in recent years. Granger and Jeon also found that causation was from inflation to unemployment in both U.S. and Britain in early periods. But Granger and Jeon did not interpret their contradictory results as the evidence that Phillips curve is as meaningless as the correlation between ice cream sales and drowning rate because Granger and Jeon did not realize that Phillips curve is constructed on two dependent variables. Bhattarai (2016) studied the relationship between unemployment and inflation and concluded that Granger causality is bidirectional. Besides, if we use Granger causality test to study the causation mechanism between ice cream sale and drowning rate, the result of Granger causality test is meaningless in the sense of scientific theory no matter we get unidirectional causality or bidirectional causality.

Thus, theoretical framework, which distinguishes all independent variables (causes) from all dependent variables (effects) in a general equilibrium model, is the only way to assure that we identify the true causal relation because dependent variable is determined by independent variable only (i.e., dependent variables are forbidden to explain each other in general equilibrium model). For example, Hoover (2013) discussed causality in economics but Hoover used one dependent variable (quantity of money, $m_{t}$ ) to explain another dependent variable (price level, $p_{t}$ ) in his model. Hoover wrote a two equations macroeconomic model (3.11 and 3.12) based on rational expectation in order to demonstrate cross-equation restriction.

$$
\begin{gathered}
m_{t}=\lambda-m_{t-1}+\varepsilon_{t} \\
p_{t}=m_{t}+\alpha \lambda-\delta+v_{t}
\end{gathered}
$$

Price level depends on quantity of money in the right hand side of equation 3.12. Quantity of money is dependent variable determined by the money supply rule of monetary authority in the right hand side of equation 3.11. Equation 3.12 is false because $m_{t}$ becomes independent variable to explain $p_{t}$. Since we can replace the quantity of money in equation 3.12 by money supply rule in the right hand side of equation 3.11 , the true equation that determines price level in Hoover's model is as below because $m_{t-1}, \alpha, \lambda, \varepsilon_{t}$ and $v_{t}$ are all given exogenously so that they are all independent (exogenous) variables.

$$
p_{t}=-m_{t-1}+(\alpha+1) \lambda-\delta+\varepsilon_{t}+v_{t}
$$

In other words, it is virtually a single equation model instead of two equations model (i.e., equation 3.11 is redundant) so that there is no cross-equation restriction in Hoover's model because neither $m_{t}$ determines $p_{t}$ nor $p_{t}$ affects $m_{t}$ in the single equation model. Quantity of money does not have explanatory power but the money supply rule of monetary authority (i.e., the right hand side of equation 3.11) has in Hoover's model because quantity of money is dependent variable and money supply rule is independent variable. Since dependent variable does not have explanatory power, dependent variable is not permitted to appear in any equation as independent variable, e.g., $m_{t}$ in Hoover's equation 3.12. As Ting (2017a) demonstrated that we are forbidden to derive any theorem from definition except that this theorem is proved before we introduce definition into theoretical framework (e.g., it is false that we derive $M V=P Y$ from the definition of income velocity, $V=P Y \div M$, because we do not prove $M V=P Y$ before we define $V=P Y \div M$ ), we are not permitted to derive a theorem from dependent variable (e.g., $m_{t}$ is not permitted to appear in equation 3.12 to prove cross-equation restriction ).

\subsection{Objective and Methodology}

Since theoretical framework is the only way to settle the debate of Phillips curve, the objective of this paper is to demonstrate that unemployment, wage and inflation rate are three dependent variables derived from not only literally theoretical framework but also mathematic models based on supply and demand analysis, especially shifting in supply curve and demand curve. In other words, there are different approaches to reach the same conclusion that Phillips curve is a particular case that economists misinterpreted the relationship between two 
dependent variables for causality (e.g., wage rate and unemployment rate are two dependent variables determined by labor supply and labor demand). Since the relationship between two dependent variables may be stable and significant in the short term but is definitely random in the long term, it explains why we observe not only negative slope Phillips curve regularly so that some economists believe that Phillips curve is still alive but also positive slope Phillips curve and flat Phillips curve occasionally so that trade-off is rejected by empirical studies. I will theoretically and mathematically demonstrate that wage rate, inflation rate and employment rise and fall simultaneously during business cycle based on Ting (2011) and Ting (2017b) so that we have observed negative slope Phillips curve frequently for centuries. Shifting in supply curve caused by supply shock (e.g., oil crisis and cost down technology) explains positive slope Phillips curve. Flat inflation Phillips curve refers to price rigidity, which is caused by shifting in both supply curve and demand curve toward the same direction according to Ting (2017b). Thus, shifting in both supply curve and demand curve theoretically explains why the slope of Phillips curve is random in the long term but stable apparently in the short run and why statistical test is useless to settle the debate on causality versus correlation of Phillips curve.

It is worth noting that there are three different types of unemployment. First, there is unemployment when market wage is higher than equilibrium wage under given labor demand curve and labor supply curve. Second, unemployment occurs or increases when labor demand curve shifts leftward, e. g., involuntary unemployment in Keynes (1936). The third type unemployment is natural rate unemployment, which is not associated with wage and inflation rate. Theoretically, I predict that the correlation between wage and volume of first type unemployment is positive while the correlation between wage and second type unemployment is negative. In other words, Phillips (1958) implicitly is associated with the second type unemployment only. Thus, I have to analyze types of unemployment when I will study Phillips curve in section 5 and section 6 . Notice that I ignore change in labor supply in this paper because Hall (2005) argued that unemployment problem depends on job finding rate instead of job searching while change in the number of job searcher arises from the change in labor supply.

The methodology of this paper is consistent with two sources. First, Klamer (1984, p. 131) recorded Solow's statement that "you cannot understand the behavior of our economy on the assumption that it is always at or near a full, or Walrasian, equilibrium, and that you cannot account for the movements that you see in output and employment on the assumption that everything you see is at the intersection of traditional supply and demand curves, and that movements are only accounted for by shifts in those curves."

Second, Gorden (2013) studied the puzzle of missing deflation of Phillips curve and wrote in page 9 "The puzzle was solved by recognizing that macroeconomics was symmetric with microeconomics in which simple supply and demand curve demonstrated that the price and quantity of wheat can be positively or negatively correlated" and "Finally macroeconomics had caught up with microeconomics: inflation could be negatively correlated with unemployment when demand shocks were dominant, as in the Vietnam-war era of low unemployment, but inflation also be positively correlated with unemployment in era like 1973-75 when sharp increases in oil prices raised inflation, reduced purchasing power and caused a recession in output and sharp rise in the unemployment rate." I interpret Gorden's statement as below. When Vietnam-war expenditure kept pulling aggregate demand curve rightward, markets were in excess demand continuously, which is equivalent to inflationary boom, so that wage, inflation and employment were pro-cyclical (i.e., the slope of Phillips curve is negative). In 1973-75, inflation Phillips curve had positive slope because oil crisis (i.e., supply shock) pushed aggregate supply curve upward and aggregate demand curve leftward inter-periods while markets were in excess supply continuously, which is equivalent to inflationary recession. Technology shock pushes supply curve to shift rightward, which also leads to positive slope inflation Phillips curve. Thus, Gorden's methodology refers to not only analogy between macroeconomics and microeconomics but also shifting in both demand curve and supply curve inter-periods as the methodology of this paper does exactly.

\subsection{Organization of This Paper}

The debate of Phillips curve involves many aspects, e.g., expectation, static equilibrium versus dynamic equilibrium, natural rate unemployment given exogenously versus cyclical unemployment determined endogenously and causality (trade-off) versus correlation (nontrade-off). These aspects are interrelated. Let's study two cases. First, natural rate unemployment hypothesis regards static equilibrium because natural rate unemployment is given exogenously and economy will restore natural rate unemployment by adjustment in real wage. If unanticipated inflation rate is given exogenously, then cyclical unemployment caused by change in unanticipated inflation rate exogenously is independent of fluctuations of GDP, which is a false conclusion because cyclical unemployment associates with fluctuation of GDP in fact. If unanticipated inflation rate is determined endogenously, then unanticipated inflation rate is dependent variable so that natural rate 
unemployment hypothesis is false because Friedman used unanticipated inflation rate, which is a dependent variable, to explain unemployment. In short, expectation, unemployment, equilibrium and causality (dependent variable versus independent variable) are interrelated in debate of Phillips curve.

Second, although unemployment and wage are two dependent variables endogenously derived from the analysis of supply and demand in this paper, the formally mathematic models and the literature analysis are different approaches based on the same analysis of supply and demand so that these different approaches interrelated from section 3 to section 5. If conclusions derived from different approaches are different, then this paper is false. In other words, it is an implicit way to support conclusions of this paper if I will derive same conclusions from different approaches, which are based on the same methodology (supply and demand analysis in this paper).

The analysis of this paper is incomplete and unsound if this paper does not take care of important aspects about the debate of Phillips curve. Therefore, each section of this paper is a theoretical framework to explain why preceding investigations about Phillips curve are wrong and establish correct approach to study Phillips curve. Thus, the sequence of sections in this paper is theoretically interrelated instead sequentially organized. But preceding sections are the foundation of the further development of theoretical framework for interrelated aspects in following sections while the inner structure of each section in this paper is based on the same methodology to derive conclusions regarding the debate of Phillips curve from the analysis of supply and demand logically and sequentially. In other words, each section provides a particular method to demonstrate that Phillips curve is correlation instead of causality. It is seems to be wrong that economists mistake this paper to be not a scientific paper but a collection of notes because sections in this paper seems to be sequentially irrelevant so that conclusions of each section in this paper are not convincible enough to verify the true idea of Phillips curve as well as a collection of reflections of real world because empirically studies listed in this paper seems to be sequentially irrelevant so that empirical studies about Phillips curve listed in this paper are not evidences to support conclusions of this paper and deny traditional approach to investigate Phillips curve theoretically and statistically.

Natural rate unemployment hypothesis is the only one theoretical model, which is widely accepted by economists to explain why Phillips curve implies temporary trade-off instead of permanent trade-off, I have ever known. Since I will count on not only supply and demand to explain why Phillips curve is built on two dependent variables so that Phillips curve is absolutely meaningless correlation instead of causal relation in both short run and long run but also pro-cyclical co-movements to explain why these two dependent variables are negatively correlated in business cycles except that supply shocks induce positive slope Phillips curve, this paper is nonsense if natural rate unemployment hypothesis is true. Besides, economists can attack this paper based on natural rate unemployment hypothesis even we do not know natural rate unemployment hypothesis is true or false. Therefore, I prove that natural rate unemployment hypothesis is false in section 2 before I display my theoretical framework about Phillips curve.

The purpose of section 3 is to explain the relationship between price and quantity in the sense of ex-ante and ex-post conceptually and literally so that I assure that relationships among wage, unemployment and inflation rate derived from mathematic models in section 4 and section 5 are dependent. In section 3, I will argue that the relationship between ex-ante price and ex-ante quantity (i.e., demand curve and supply curve) is mathematic mapping instead of cause and effect as well as the relationship between ex-post price and ex-post quantity is statistical correlation instead of causality because both ex-post price and ex-post quantity are dependent variable (effect) while both supply and demand are independent variable (cause). Thus, I literally demonstrate that the trade-off between wage and unemployment and the trade-off between inflation and unemployment are two cases of misunderstanding the relationship between price and quantity in the sense of not only ex-ante but also ex-post. I also demonstrate that both real price (e.g., real interest rate and real wage) and relative price are definition, which is neither independent variable nor dependent variable, so that we are not permitted to construct economic theory on real price (e.g., Friedman (1968) built natural rate unemployment hypothesis on real wage and Phelps (1967) constructed his model of inflation Phillips curve on real interest rate) and relative price (e.g., the business cycle theory of Lucas (1980) is based on the confusion between change in relative prices and change in nominal prices).

Following section 3, I develop a microeconomic model in section 4 and a macroeconomic model in section 5 in which wage, inflation rate and employment are all dependent variables correlated positively intending to show that arguments in section 3 are true. In section 4, I construct a microeconomic model based on Ting (2017b) to study the output effect on employment and wage in firm theory when both supply curve and demand curve shift inter-periods. Ting (2017b) demonstrated that product supply curve always shifts toward the same direction as product demand curve shifts. Further, labor demand curve shifts toward the same direction as product supply 
curve shifts because labor demand is derived from supply of product. Since output effect arises from shifting in product demand curve (e.g., change in aggregate income leads to change in demand for products first and then supply of products next), the firm's labor demand curve shifts toward the same direction as product demand curve shifts. Consequently, firm theory demonstrates that wage, employment, product price and volume of output are all dependent variables, which are positively correlated each other (i.e., Phillips curve) in time series under the circumstance that both supply curve and demand curve shift inter-periods. This conclusion suggests that macroeconomic employment theory in section 5 must be analogous to microeconomic employment theory developed in section 4 because employment in the sense of macroeconomics is aggregation of employment in the sense of microeconomics so that they have the same essential characteristics.

Ting (2011) built a theoretical business cycle model on supply and demand as well as budget constraint, which generates pro-cyclical co-movement of wage rate, employment, price level and aggregate income in current period by excess demand and excess supply. Notice that excess demand (supply) in current period implies boom and expansion (recession and contraction) so that both excess demand and excess supply are essential characteristics of business cycle. Since wage, price level (inflation rate) and employment are all dependent variables in Ting (2011), there is no causality (i.e., neither temporary trade-off nor permanent trade-off) on Phillips curve. Since Ting (2011) unrealistically assumed that all labors are self-employee, Ting (2011) concluded that input markets are in equilibrium if output markets are in equilibrium. Thus, there is no obstacle to prevent economy from full employment. Since Ting (2011) is not able to explain persistent unemployment and persistent unemployment is interpreted as the evidence that there is no trade-off on Phillips curve, Ting (2011) is incomplete and unsound. In section 5, I replace the self-employee assumption by the realistic description that firms hire labor to produce output. In addition to pro-cyclical co-movement in Ting (2011), I reach a new and crucial conclusion that labor market is possible to be in disequilibrium when aggregate income is in equilibrium. This conclusion demonstrates the existence persistent unemployment and slow recovery as well as shows that persistent unemployment is a statistical phenomenon (i.e., dependent variable) instead of exogenous factor.

The purpose of section 5 and section 6 is to further discuss type of unemployment following section 3 and section 4 because the type of unemployment in section 4 and section 5 is caused shifting labor demand curve due to income effect and output effect while classic economics and natural rate unemployment concern change in unemployment caused by change in wage (wage substitution effect). But both classic economics and natural rate unemployment hypothesis have the same fatal mistake that wage is impossible to rise when there is excess supply of labor (i.e., unemployment) so that unemployment is impossible to increase without exogenous interference, e.g., unanticipated inflation rate and wage rigidity due to union and minimum wage law. In section 6, I interpret Keynesian's involuntary unemployment as the unemployment caused by endogenously leftward shifting in labor demand curve (i.e., cyclical unemployment), not caused by wage rigidity due to the reason that wage rigidity makes market wage is higher than equilibrium wage. Thus, involuntary unemployment and Phillips curve are two pro-cyclically statistical phenomena. Besides, involuntary unemployment concerns increase in unemployment under either lower wage or given wage instead of total number of unemployment, friction unemployment and job searchers conceptually. To summarize, section 5 and section 6 discuss what type unemployment macroeconomics regards and it is crucial that the model developed from section 4 to section 6 handle aspects of unemployment about Phillips curve in macroeconomics I have ever known because if a single methodology cannot take care of all aspects about an event, this methodology is incomplete and unsound. In other words, this paper fails to explain Phillips curve in the sense of scientific paper.

In section 7, I remark that the study of Phillips curve in this paper suggests that policy instrument should be independent variable and policy target should be dependent variable as well as implies that we fail to forecast results of economic policy (i.e., econometric policy evaluation) by econometric model because economists construct econometric model on relationships between dependent variables and dependent variables (e.g., Phillips curve) instead of relationships between independent variables and dependent variables. In other words, parameters drift is not the reason of failure of econometric policy evaluation but missing causality is if parameters represent relationships between dependent viable and dependent variable. For example, drift in coefficients of Phillips curve is a wrong diagnose for the failure of econometric policy evaluation because coefficients of Phillips curve are random substantially.

\section{Natural Rate Unemployment Hypothesis Is False}

In Friedman (1968), natural rate unemployment hypothesis is composed of three key ideas, which are interwoven to each other. First, Friedman (1968, p. 8) stated "The "natural rate of unemployment", in other words, is the level that would be ground by the Walrasian system of equations". Second, Friedman (1968, p. 10) addressed "Indeed, the simultaneous fall in ex post in real wage to employers and rise ex ante in real wage to employees is 
what enabled employment to increase" and "the rise in real wages will reverse the decline in unemployment, and then lead to a rise, which will tend to return unemployment to its former level." Third, Friedman (1968, p. 11) wrote "The temporary trade-off comes not from inflation per se, but from unanticipated inflation, which generally means, from a rising rate of inflation...A rising rate of inflation may reduce unemployment, a higher rate will not...It cannot use its controls over nominal quantity to peg a real quantity." In short, natural rate unemployment hypothesis is dynamic process of automatic equilibrium restoration mechanism, which is composed of a causal relation chain like domino. Asymmetrical information creates unanticipated inflation rate, which determines change in real wage and actual unemployment. But learning will revise inflation expectation so as to eliminate unanticipated inflation rate and restore natural rate unemployment. Asymmetrical information and learning are the final cause while unanticipated inflation rate is the effect. Unanticipated inflation is the secondary cause and change in real wage is the direct effect of unanticipated inflation rate but the secondary effect of learning and asymmetrical information. Change in real wage is the third class cause and change in actual unemployment is the final effect. Like the case of Hoover above, we are able to replace unanticipated inflation rate and change in real wage by asymmetric information and learning as well as substitute unanticipated inflation rate for change in real wage.

Friedman (1968) did not link unanticipated inflation rate to fluctuation of GDP so that employment depends on wage only. But Lucas (1980) argued that entrepreneurs mistake the change in absolute price for change in relative price due to asymmetric information (unanticipated inflation) so that entrepreneurs produce more or less products and employ more or less labor than economy actually needs. For example, if money supply is greater than money demand due to asymmetric information about money supply (i.e., unanticipated increase in money supply), unanticipated inflation rate will be greater than zero based on Fisher's exchange equation so that unemployment will be lower than natural rate unemployment and GDP will rise. If money is neutral, both GDP and unemployment should return to its former level. Thus, the first idea of Friedman implies that natural rate unemployment hypothesis requires that static equilibrium should exist in every market due to neutrality of money except that labor market is in disequilibrium because natural rate unemployment requires that labor supply should be greater than labor demand. It implies that both supply curve and demand curve are given so that price substitution effect restores equilibrium price and quantity. Otherwise, output and unemployment will not return to its former level, which is emphasized in Friedman's second idea. For example, real wage rate and unemployment rate may not return to its former level if recovery is caused by increase in net aggregate investment because GDP returns to its former level now but both aggregate supply curve and labor demand curve will shift in the future due to change in capital stock. Thus, the equilibrium economy reaches is dynamic so that unemployment will be greater or less than natural rate unemployment in the future.

Since static equilibrium is the premise of natural rate unemployment hypothesis implicitly but dynamic equilibrium (i.e., shifting in supply curve and demand curve emphasized by Solow and Gorden) is normal in real world, static equilibrium is false premise on which we construct theory to explain real word. The theory constructed on false premises is false even we do not make any logical mistake. For example, we can derive true conclusions (e.g., sun rise in east and sun set at west) from false premises (e.g., sun rotates earth from east to west). I conclude that the economic theory built on static equilibrium is false to explain Phillips curve, e.g., natural rate unemployment hypothesis.

In Friedman's third idea, Friedman links the fluctuation of real wage and unemployment to rising rate of inflation (i.e., unanticipated inflation rate). Since labors underestimate the future inflation rate due to asymmetric information (i.e., rise in ex-ante real wage in Friedman's second idea), the real wage that labors will receive is less than labors expected if labors accept job. But a rational labor will revise his expectation of inflation and quit job if the ex-post real wage he receives is less than he expected due to unanticipated inflation rate. Since unanticipated inflation rate diminishes due to learning, both unemployment and real wage will return to its former level while other markets restore its static equilibrium. Thus, real wage rises when unemployment rises and real wage falls when unemployment falls so that we should observe countercyclical pattern of real wage under natural rate unemployment hypothesis. That is, substitution effect of real wage on labor demand curve discussed in Friedman's second idea restores natural rate unemployment so that the relationship between real wage and unemployment is positive (i.e., countercyclical wage and positive slope of real wage Phillips curve). Friedman (1968) used the case of Brazil inflation to support natural rate unemployment hypothesis because both real wage and unemployment increased (decreased) in Brazil when inflation rate of Brazil fell (rose).

But there are many empirical evidences against countercyclical real wage. Marczak and Gómez (2012) used wavelet to study U.S. real wage and found that U.S. real wage was cyclical between 1965 and 1985 but countercyclical after 2000. Messina et.al (2009) studied real wage in different countries and report that U.S., 
U.K., Germany and Japan had cyclical real wage pattern while Canada, Spain, Ireland and New Zealand had countercyclical real wage pattern. Empirical studies support the argument that the relationship between ex-post wage and ex-post unemployment is random in time series because both labor demand curve and labor supply curve shifts. If real wage determines unemployment as Friedman predicted, real wage is impossible to be not only cyclical but also countercyclical in empirical studies. Bils (1985) not only found cyclical real wage but also suggested that we have to concern the impact arising from shifting in labor demand curve on real wage. Since shifting in labor demand curve implies that unemployment will not return to its former level, Bils' suggestion denies natural rate unemployment hypothesis implicitly.

Great Depression is an interesting case of short run Phillips curve. Table 1 in Lucas (1972), which is listed below, contains data to observe real wage rate, nominal wage rate, inflation rate and unemployment rate between 1929 and 1939. Notice that "Normal" regards data modified by Lucas based on his particular labor supply theory in order to test his argument about unemployment. Thus, columns of "Normal" does not regard Phillips curve we observe directly and substantially.

\begin{tabular}{cccccc}
\hline Year & $\begin{array}{c}\text { Unemployment } \\
\text { Rate } U_{t}\end{array}$ & $\begin{array}{c}\text { Money Wage Rate } W_{t} \\
(\$)\end{array}$ & $\begin{array}{c}\text { "Normal" Money Wage } \\
\text { Rate } W_{t}^{*}\end{array}$ & $\begin{array}{c}\text { GNP Deflator } \\
p_{t}(1958=1)\end{array}$ & $\begin{array}{c}\text { "Normal" GNP } \\
\text { Deflator } p_{t}^{*}\end{array}$ \\
\hline 1928 & .04 & .55 & .56 & .50 & .51 \\
1929 & .03 & .56 & .57 & .51 & .51 \\
1930 & .09 & .56 & .58 & .49 & .50 \\
1931 & .16 & .53 & .57 & .45 & .48 \\
1932 & .24 & .48 & .55 & .40 & .45 \\
1933 & .25 & .46 & .52 & .39 & .43 \\
1934 & .22 & .51 & .53 & .42 & .43 \\
1935 & .20 & .52 & .53 & .43 & .43 \\
1936 & .17 & .53 & .54 & .43 & .43 \\
1937 & .14 & .57 & .56 & .44 & .44 \\
1938 & .19 & .58 & .57 & .43 & .44 \\
1939 & .17 & .58 & .59 & .44 & .44 \\
1940 & .15 & .60 & .60 & .47 & .45 \\
1941 & .10 & .66 & .63 & .53 & .48 \\
1942 & .05 & .76 & .68 & .57 & .51 \\
1943 & .02 & .84 & .75 & .58 & .50 \\
1944 & .01 & .90 & .88 & & .56 \\
1945 & .02 & .98 & & & .54 \\
\hline
\end{tabular}

Both wage Phillips curve and inflation Phillips curve worked very well from 1929 to 1933 because nominal wage, price level and employment declined severely and simultaneously (i.e., pro-cyclical co-movements) while real wage decreased mildly. There are two facts between 1934 and 1939. First, the slope of real wage Phillips curve was negative but Friedman (1968) predicted positive slope. Second, inflation rate was almost equal to zero while unemployment rate declined (i.e., price rigidity and horizontal inflation Phillips curve) but the slope of nominal wage Phillips curve is negative apparently. It demonstrates that wage Phillips curve is different from inflation Phillips curve but natural rate unemployment hypothesis ignores this difference fully. If unanticipated inflation rate is greater than zero, then actual inflation rate is greater than zero so that the slope of inflation Phillips curve we observe is supposed o be negative (i.e., horizontal inflation Phillips curve is impossible). Thus, price rigidity implies that unanticipated inflation rate is equal to zero. If unanticipated rate is equal to zero, then natural rate unemployment hypothesis predicts that unemployment rate will not change. Thus, horizontal inflation Phillips curve is impossible under natural rate unemployment hypothesis. If anticipated inflation is greater than zero due to recovery but unanticipated inflation rate is negative due to hysteresis caused by deflationary depression so that actual inflation rate is equal to zero (i.e., price rigidity), then negative unanticipated inflation rate predicts that both ex-post real wage and ex-post unemployment will rise according to natural rate unemployment hypothesis. But real wage rose and unemployment decline between 1934 and 1939 in Great Depression. Thus, horizontal inflation Phillips curve is the empirical evidence that natural rate unemployment hypothesis is false.

If there is an alternative theory that explains price rigidity, horizontal inflation Phillips curve and negative slope wage Phillips curve between 1934 and 1939 simultaneously, the alternative theory is a supplementary evidence 
to show that natural rate unemployment hypothesis is false. Ting (2017b) argued that proportionally rightward shifting in both aggregate supply curve and aggregate demand curve causes not only price rigidity but also increase in GDP and employment (i.e., horizontal inflation Phillips curve) while the rise in nominal wage is caused by increase in labor productivity. Note that New Keynesian economics needs hysteresis to simulate horizontal inflation Phillips curve; otherwise New Keynesian cannot explain price rigidity between 1934 and 1939 while unemployment declined. Further, if hysteresis causes horizontal inflation Phillips curve, then wage Phillips curve is supposed to be horizontal between 1934 and 1939 because wage depends on price expectation in New Keynesian economics, e.g., Galí (2015). Since the slope of wage Phillips curve was negative while the slope of inflation Phillips curve was horizontal from 1934 to 1939, hysteresis is false hypothesis to explain Phillips curve.

If anticipated inflation rate is determined endogenously, unanticipated inflation is definition instead of independent variable because unanticipated inflation rate is the difference between actual inflation rate and anticipated inflation rate. As Ting (2017a) showed that income velocity is definition so that it is wrong we use income velocity as independent variable to explain nominal aggregate income, natural rate unemployment hypothesis is false because unanticipated inflation rate is definition and Friedman used unanticipated inflation rate as independent variable to explain actual unemployment. If both anticipated inflation rate and unanticipated inflation rate are given exogenously to determine actual inflation rate, supply and demand is not permitted to determine ex-post market price in each market and actual inflation rate endogenously in general equilibrium model because the actual inflation rate, the actual wage rate and the actual unemployment rate derived from supply and demand may be different from the actual inflation rate, the actual wage rate and the actual unemployment rate determined by exogenous anticipated inflation rate and exogenous unanticipated inflation rate.

Let's study several paradoxes caused by the conflict between unanticipated inflation rate and the analysis of supply and demand. Friedman $(1968$, p. 8$)$ wrote "A lower level of unemployment is an indication that there is excess demand for labor that will produce upward pressure on real wage rate. A higher level of unemployment is an indication that there is an excess supply of labor that will produce downward pressure on real wage rate." Friedman's analysis of excess demand for labor and excess supply of labor demonstrates that unemployment and real wage are dependent variable (effect), determined by supply and demand (cause) endogenously. Since Friedman argued that rise in real wage caused by negative unanticipated inflation rate raises unemployment in his second idea and the case of Brazil inflation, unemployment is dependent variable (effect) and real wage is independent variable (cause). Friedman (1968) is self contradictory.

Since static equilibrium is the premise of natural rate unemployment hypothesis, both demand curve and supply curve are given. When market real wage is lower than equilibrium real wage and both labor supply curve and labor demand curve are given, labor market is in excess demand so that there is no unemployment because every person who wants to work at market real wage is employed by firms. In this case, real wage and employment will rise until labor market reaches static equilibrium. Once labor market reaches static equilibrium, real wage should stop rising so that economy will not return to natural rate unemployment.

Natural rate unemployment must correspond to a certain level of real wage, say $w_{N} \cdot w_{N}$ is greater than equilibrium real wage. Otherwise, labor market is excess demand so that there is neither unemployment nor natural rate unemployment. If we assume that natural rate of unemployment is 4 percent and actual unemployment rate is 2 percent, then Friedman argued that real wage should rise in order to return actual unemployment rate to 4 percent in his second idea. But Friedman's analysis of excess supply of labor predicts that real wage will fall and employment (unemployment) rises (falls) so that unemployment will not return to 4 percent. Thus, if Friedman's second idea is true, then real wage rise due to negative unanticipated inflation rate (e.g., inflation rate falls abruptly so that inflation rate is underestimated) so that excess supply of labor plays no role to determine real wage. Suppose that actual unemployment rate rises from 6 percent to 8 percent during recession while both labor demand curve and labor supply curve are given. Since unemployment rate rises and both labor demand curve and labor supply curve are given, ex-post real wage must rise. If the analysis of supply and demand is true, ex-post real wage is impossible to rise when labor market is excess supply. In this case, natural rate unemployment hypothesis requires that unanticipated inflation rate should be negative so that both ex-post real wage and ex-post unemployment rise. Thus, natural rate unemployment hypothesis based on unanticipated inflation rate is inconsistent with Friedman's analysis of excess supply of labor.

Of course, we can interpret excess demand for labor (excess supply of labor) as the situation that unemployment rate is lower (higher) than natural rate of unemployment. The positive unanticipated inflation rate, which is given exogenously, makes real wage be lower than $w_{n}$ so that labor market is in excess demand and actual 
unemployment is less than natural rate unemployment. Then, excess demand for labor leads to rise in both real wage and unemployment (i.e., countercyclical real wage) because economic agents revise their price expectation. Thus, unanticipated inflation rate returns to zero, real wage returns to $w_{n}$ and unemployment returns to natural rate unemployment. Consequently, natural rate unemployment hypothesis looks so far so good. Reconsider the case that negative unanticipated inflation rate makes real wage rise so that unemployment rate rises from 6 percent to 8 percent under given labor demand curve and labor supply curve while natural rate of unemployment is 4 percent. Since 6 percent unemployment is higher than natural rate unemployment, labor market is in excess supply and excess supply of labor predicts fall in real wage and unemployment. Friedman's analysis of excess supply of labor is contrary to natural rate unemployment hypothesis once more.

Further, negative unanticipated inflation rate (i.e., rise in real wage) pushes market unemployment rate to deviate from natural rate of unemployment when market unemployment rate is greater than natural rate of unemployment and market real wage is higher than $w_{N}$. It means that economy is divergent. But negative unanticipated inflation rate makes labor market converge to natural rate unemployment when market unemployment rate is lower than natural rate of unemployment and market real wage is lower than $w_{N}$ but higher than equilibrium wage. Thus, negative unanticipated inflation rate causes a new paradox that the relationship between negative unanticipated inflation rate and stability of natural rate unemployment is random. I conclude that paradoxes in Friedman (1968) are caused by unanticipated inflation rate because unanticipated inflation rate is definition and we are not permitted to use definition as independent variable to develop any theorem, which is not proved before we introduce definition into theoretical framework.

It is worth noting that excess supply of labor cannot explain the negative relationship between wage and unemployment in recession (e.g., deflationary recession between 1929 and 1933) if we assume that both labor supply curve and labor demand curve are given because unemployment exists if and only if there is excess supply of labor so that the relationship between wage and unemployment is positive under static equilibrium. If labor demand curve shifts leftward, it is possible that the wage in current period is lower than the wage in last period and the volume of unemployment in current period is greater than the volume of unemployment in last period. If labor demand curve shifts rightward, it is possible that the wage in current period is higher than the wage in last period but the volume of unemployment is less the volume of unemployment in last period. Thus, we get pro-cyclical co-movement during business cycle (e.g., negative slope wage Phillips curve). Thus, the analysis of supply and demand in business cycle theory refers to change in supply and demand caused by shifting in either demand curve or supply curve as Solow and Gorden stated.

To summarize, natural rate unemployment hypothesis is false for six reasons. First, natural rate unemployment hypothesis implies countercyclical real wage but we observe cyclical real wage. Second, we observe horizontal inflation Phillips curve and positive slope inflation Phillips curve in the short run but natural rate unemployment hypothesis predicts negative slope inflation Phillips curve is in the short run (i.e., temporary trade-off). If conclusions of a theory are against observations, then this theory is false.

Third, there are two employment theories in Friedman (1968). One is based on unanticipated inflation rate and real wage to predict positive relationship between real wage and unemployment. The other is built on excess demand of labor and excess supply of labor to suggest the negative relationship between real wage and unemployment. Thus, Friedman (1968) is self contradictory. Fourth, real world is in dynamic equilibrium because both supply curve and demand curve shift actually. Thus, static equilibrium is false premises on which natural rate unemployment hypothesis relies to explain Phillips curve because Phillips curve is a phenomenon arising from real world. We construct false theory if premise is false. Fifth, unanticipated inflation rate is not independent variable to explain actual unemployment but definition to explain nothing. Sixth, natural rate unemployment hypothesis cannot explain why the pattern of wage Phillips curve is different from the pattern of inflation Phillips curve between 1933 and 1939.

\section{The Relationship between Price and Quantity}

\subsection{Ex-Ante Price and Quantity versus Ex-post Price and Quantity}

The relationship between price and quantity on supply (demand) curve is positive (negative) in the sense of ex-ante because demand (supply) curve is buyers' (sellers') plan while buyers (sellers) have not yet entered market to fulfill their plans by transaction. We derive market supply (demand) curve in the sense of ex-ante from supply (demand) curves of each individual economic agent by aggregation. Although the relationship between ex-ante price and ex-ante quantity on (market) demand curve is opposite to (market) supply curve, there is no conflict if we study (market) demand curve and (market) supply curve separately. When we take supply and demand as a whole to form market, one ex-ante market price corresponds to not only the ex-ante market quantity 
on market demand curve but also the ex-ante market quantity on market supply curve. Since one ex-ante market price maps to two different market ex-ante quantities except equilibrium, ex-ante market price cannot determines market ex-ante quantity. For example, the ex-ante market quantity on market supply curve rises but the ex-ante market quantity on market demand curve falls when ex-ante market price rises. Consequently, we do not know ex-ante market quantity will rise or fall when ex-ante market price changes. Conversely, one ex-ante market quantity corresponds to two different ex-ante market prices except equilibrium so that ex-ante market quantity cannot explain ex-ante market price, either. Thus, there is no causal relationship between the ex-ante market price and the ex-ante market quantity

When buyers and sellers transact in market, both market price and market quantity we observe are ex-post in real world. Both ex-post market price and ex-post market quantity are determined by market supply and market demand endogenously, not by either ex-ante market price or ex-ante market quantity. If market is in disequilibrium, excess demand (supply) will drive both ex-post market price and ex-post market quantity to increase (decrease). Thus, the analysis of supply and demand predicts that the relationship between ex-post market price and ex-post market quantity is positive in the sense of statistics whether we study macroeconomics (e.g., both Phillips (1958) and Friedman (1968)) or microeconomics. In other words, neither ex-ante market price nor ex-ante market quantity is exogenous variable in economic theory to determine either ex-post market price or ex-post market quantity. Since both ex-post market price and ex-post market quantity are determined by market supply and market demand endogenously, both ex-post market price and ex-post market quantity are dependent variable. Since dependent variable explain nothing, ex-post market price and ex-post market quantity are irrelevant each other from the view point of cause and effect. Consequently, there is no any causal relation between ex-ante price and ex-post quantity, ex-ante quantity and ex-post price, ex-ante price and ex-post price, ex-ante quantity and ex-post quantity, ex-ante price and ex-ante quantity and ex-post price and ex-post quantity.

We can use another approach to analyze the relationship between price and quantity and reach the same conclusion in the last paragraph that there is no causal relation between price and quantity theoretically. When we read demand curve, we can reach two conclusions. First, if price falls, then economic agents will buy more. Second, if economics agents buy more, then price declines. Thus, we can either use ex-ante price to explain ex-ante quantity or use ex-ante quantity to determine ex-ante price so that the relationship between ex-ante price and ex-ante quantity on demand curve is circular reasoning. In other words, the relationship between ex-ante price and ex-ante quantity on supply curve and demand curve should be one on one mapping in the sense of mathematics instead of causality. Otherwise we are self-contradictory due to circular reasoning. For example, we study the optimum volume of capital under the maximum return rate on capital hypothesis as Ting $(2009,2017 \mathrm{~b})$ proposed.

$$
\begin{gathered}
\operatorname{Max} \frac{P Q(K, N)-w N}{K} \\
\left(\frac{\partial P}{\partial Q} \frac{\partial Q}{\partial K} Q+\frac{\partial Q}{\partial K} P\right) K=P Q-w N \\
\frac{\partial P}{\partial K}=\frac{\partial P}{\partial Q} \frac{\partial Q}{\partial K} \\
\left(\frac{\partial Q}{\partial P} \frac{\partial P}{\partial K} P+\frac{\partial P}{\partial K} Q\right) K=\left(\frac{\partial Q}{\partial P} \frac{\partial P}{\partial Q} \frac{\partial Q}{\partial K} P+\frac{\partial P}{\partial Q} \frac{\partial Q}{\partial K} Q\right)=\left(\frac{\partial Q}{\partial K} P+\frac{\partial P}{\partial Q} \frac{\partial Q}{\partial K} Q\right)=P Q-w N \\
K=\frac{P Q-w N}{P\left(1+\frac{1}{\eta}\right) \frac{\partial Q}{\partial K}}
\end{gathered}
$$

Where $P, Q, K, N$ and $\eta$ are price, quantity (production function), capital, labor and price elasticity respectively. Since Ting (2017a) showed that mass does not depend on force in $m=F \div a$ because mass is indeterminate when acceleration is zero, $\frac{\partial F}{\partial m}$ is true in $F=m a$ but $\frac{\partial m}{\partial F}$ is false in $m=F \div a$ theoretically from the view point of cause and effect. It implies that derivative is not permitted to be reversed if there is causal relation between two variables. Since it is true that both $\frac{\partial P}{\partial Q}$ in equation (4) and $\frac{\partial Q}{\partial P}$ in equation (2) lead to equation (5), it means that the relationship between ex-ante price and ex-ante quantity on demand curve $(P Q(K, N))$ in equation (1) is one on one mapping mathematically instead of causality. Thus, it is false that we explain ex-ante quantity by ex-ante price and vice versa. 
Consider maximum profit hypothesis.

$$
\begin{gathered}
\operatorname{Max} P Q-C(Q) \\
\frac{\partial P}{\partial Q} Q+P-\frac{\partial C(Q)}{\partial Q}=0
\end{gathered}
$$

Where $C(Q)$ is cost function. Since cost function is independent of output price (i.e., $\frac{\partial C(Q)}{\partial P}$ does not exist theoretically) but is dependent on quantity of output, maximum profit hypothesis misleads us to accept that ex-ante quantity is cause and ex-ante price is effect. Similarly, Giffen goods drive us to believe that ex-ante price is cause and ex-ante quantity is effect because one ex-ante quantity correspond two ex-ante prices on backward demand curve, which is caused by income effect arising from increase in price, so that price cannot be a function of quantity (i.e., $P=f(Q)$ does not exist when product is Giffen good) but quantity can be a function of price (i.e., $Q=G(P)$ exists when product is Giffen good). If there is increase return to scale, one ex-ante price corresponds to two ex-ante quantities on supply curve because firms can supply different quantities of product while price is given (i.e., $Q=G(P)$ does not exist).

If we use price (quantity) as independent variable to forecast quantity (price) in econometric model, we shall fail because both demand curve and supply curve shift inter-periods. Consider Lucas' aggregate supply function, $y=a\left(P-P^{e}\right)$ in which GDP (i.e., quantity of total output and real factor) in the sense of supply is effect and unanticipated inflation rate (price and nominal factor) is cause. When aggregate supply curve shifts due to change in production scale (i.e., net aggregate investment is greater or less than zero so that capital stock changes), it means that coefficient $a$ in Lucas' aggregate supply function drifts (i.e., Lucas' aggregate supply function shifts as Phillips curve shifts). Thus, Lucas' aggregate supply function is always biased systematically because Lucas' aggregate supply function like Phillips curve is also a particular case that economists misinterpret the correlation between ex-post price and ex-post quantity for causal elation.

To summarize, the relationship between ex-ante market price and ex-ante market quantity is mathematic mapping and the relationship between ex-post market price and ex-post market quantity (e.g., Phillips curve) is correlation instead of causality which will be random in inter-periods due to shifting in supply curve and demand curve but positively correlated in current period due to excess demand and excess supply under given supply curve and demand curve.

\subsection{Real Price versus Nominal Price}

The concept of real price consists of two ideas. One is relative price. The other is purchasing power (e.g., real wage and real interest rate). I discuss relative price first. There are $n$ nominal prices in nominal price regime and $\frac{n(n-1)}{2}$ relative prices in relative price regime if there are $n$ products except money. Economists state that the difference between relative price regime and nominal (absolute) price regime is numéraire, which makes the number of nominal prices be less than the number of relative price under the same number of goods while nominal prices and relative prices carry the same volume of price information to allocate resources. If there are $\frac{n(n-1)}{2}$ relative prices and $n$ goods, then all goods exchange each other. In this case, every good can be the candidate of commodity money, which is numéraire. Thus, relative price regime will evolve to nominal price regime automatically under this circumstance because nominal price regime is more efficient than relative price regime to transmit price information. I conclude that there are goods which do not exchange each other in relative price regime because there is no numéraire in relative price regime.

Consider a barter economy in which there are four goods and product $X_{1}$ exchanges with product $X_{2}$ only while product $X_{3}$ exchanges with product $X_{4}$ only. Thus, there are only two relative prices. One is the relative price between $X_{1}$ and $X_{2}$. The other is the relative price between $X_{3}$ and $X_{4}$. There is no relative price between $X_{1}$ and $X_{3}, X_{1}$ and $X_{4}, X_{2}$ and $X_{3}$ and $X_{2}$ and $X_{4}$. Consequently, relative price regime is composed of many sub relative price regimes and the total number of relative price may be less than the total number of nominal price. Consider another case that $X_{1}, X_{2}$ and $X_{3}$ exchange each other while $X_{4}$ exchange with $X_{3}$ only. We 
can infer the relative price between $X_{1}$ and $X_{4}$ from the relative price between $X_{1}$ and $X_{3}$ as well as derive the relative price between $X_{2}$ and $X_{4}$ from the relative price between $X_{2}$ and $X_{3}$. Thus, $X_{1}, X_{2}$ and $X_{3}$ are qualified to be numéraire. In other words, if we use $1,2 \ldots$ and $n$ to represent goods and these $n$ numbers can link each other to be a permutation, then we have nominal price regime because there is at least one numéraire. In the case above, 1234, 2134, 4312 and 4321 are permutation, not 132 (due to the reason that product $X_{2}$ does not exchange with product $X_{4}$ ), 231 (because there is no transaction between product $X_{1}$ with product $X_{4}$ ), 312, 321 , and 34 .

Suppose that we double the size of the second example in the last paragraph, in which there are two groups of products and there is no transaction between these two groups. Let $X_{1}, X_{2}$ and $X_{3}$ be candidate of numéraire in the first group and $X_{5}, X_{6}$ and $X_{7}$ be candidate of numéraire in the second group. Since we can replace relative price regime by nominal price regime in each product group, there are two sub nominal price regimes. Thus, there are two different kinds nominal price economy. One is nominal price economy if there is one common numéraire in all markets. The other is sub nominal price economy in which there is at least one sub numéraire in each product group.

It is relative prices economy that each product group has two goods only because we can establish sub nominal price economy if the number of products is more than two in each product group. Since there is no transaction between any two product groups in relative price economy, the number of relative prices in relative price economy is equal to the number of groups $\left(\frac{n}{2}\right)$ instead of $\frac{n(n-1)}{2}$ while the number of goods is $n$.

The key point of arguments above is that the concept of "total" does not exist in both relative price economy and sub nominal price economy. For example, you do not know your total wealth when you own one unit $X_{1}$ and two units $X_{3}$ in a four goods relative price economy while $X_{1}$ and $X_{3}$ are not in the same product group because there is no relative price between $X_{1}$ and $X_{3}$ so that we cannot add one unit $X_{1}$ and two units of $X_{3}$ together by a common unit for both $X_{1}$ and $X_{3}$ because common unit is identical to numéraire in this case. Thus, nominal price economy is super to relative price economy because every product has its value in terms of numéraire (i.e., numéraire is the common unit to measure the value of each product) under nominal price economy so that we know total expenditure, total revenue, profit (i.e., the difference between total cost and total revenue) and so on even some goods do not exchange each other. In other words, the information about value of non-exchange goods distinguishes nominal price economy from relative price economy. Thus, it is wrong that nominal price regime is super to relative price regime because the number of nominal price is less than the number of relative price given the number of goods.

Once we clarify the concept of relative price economy, we can compare nominal price model with relative price model. Let's review maximum utility hypothesis.

$$
\begin{gathered}
\operatorname{Max} U\left(X_{1} \ldots X_{n}\right)+\lambda\left(Y-\sum_{i=1}^{n} P_{i} X_{i}\right) \\
\frac{\partial U}{\partial X_{i}}=\lambda P_{i} \\
\frac{\partial U}{\frac{\partial X_{i}}{\partial U}}=\frac{P_{i}}{\partial X_{j}}
\end{gathered}
$$

Where $Y, P_{i}$ and $X_{i}$ are nominal income, nominal price and quantity of product $i$ respectively. Since we cannot calculate both total revenue and total expenditure by relative price and quantity, the budget constraint in equation (8) does not exist under relative price economy as well as sub nominal price economy. In other words, nominal price economy is the sufficient condition for equation (8) implicitly. Since budget constraint and relative price economy are mutually exclusive, a rational economic agent, who makes his own decision based on maximum utility hypothesis, must live in nominal price economy except that a rational economic agent, who lives in either sub nominal price economy or relative price economy and makes his own decision based on maximum utility hypothesis, only purchases and sales goods that are in a particular product group.

Nominal prices in equation (8) are given exogenously. By maximum utility hypothesis, we can assume that the nominal price of $X_{i}$ varies and other nominal prices are fixed so that we derived demand curve for $X_{i}$ of an individual consumer from maximum utility hypothesis (i.e., nominal price regime is the sufficient condition for demand curve implicitly). It may mislead us to accept the conclusion that price is cause and quantity is effect. Since maximum utility under given nominal income and minimum cost under given utility are duel, we reach the same solution when we either use change in quantity to pursue optimum under maximum utility hypothesis or use change in nominal price to reach optimum under minimum cost hypothesis. Thus, the relationship between 
ex-ante nominal price and ex-ante quantity on demand curve of an individual economic agent is mathematic mapping because maximum utility is cause while quantity is effect due to the reason that nominal prices are given exogenously so that there is no causal relation between ex-ante price and ex-ante quantity.

Since equation (9) is the sufficient condition for maximum utility mathematically and equation (10) is transformed from equation (9), equation (10) does not imply that market supply and market demand determine ex-post market relative price directly. Thus, relative price is definition in a general equilibrium model because all relative prices are not determined by market supply and market demand endogenously but are inferred from all ex-pot market nominal prices while each ex-post market nominal price is dependent variable determined by market supply and market demand in a particular market endogenously. For example, there is a general equilibrium model that determines ex-post market nominal price $P_{i}$ and $P_{j}$ so that we can define the ratio of $P_{i}$ to $P_{j}$ to be the ex-post market relative price $\left(P_{i j}\right)$ between $X_{i}$ and $X_{j}$ while this general equilibrium model does not determine any ex-post market relative price by market supply of and market demand for $X_{i}$ and $X_{j}$ endogenously and directly. Thus, business cycle caused by the confusion between nominal price and relative price is impossible in nominal price economy because all economic agents make decision based on information arising from excess demand and excess supply, not nominal price and relative price. Since Lucas and Sargent ignored that excess market demand and excess market supply can provide correct information about the situation of economy, Lucas and Sargent (1979) incorrectly argued that the confusion between relative price and nominal price leads economic agents to make wrong decision about production so that unanticipated inflation causes fluctuation of aggregate income like the confusion between real wage and nominal wage leads labors to accept lower real wage so that unanticipated inflation rate drives employment to fluctuate under natural rate unemployment hypothesis.

Ting (2017a) proved that Fisher's exchange equation is a false model because income velocity is definition but income velocity is used to explain nominal GDP as an independent variable in quantity theory of money by monetarists. Since the relative price in equation (10) is transformed from two nominal prices given exogenously in equation (9), the relative price in equation (10) is definition. Since definition is neither independent variable nor dependent variable in a model (e.g., relative prices do not appear in equation (8)), equation (10) does not mean that relative price does matter due to the reason that economic agents make decision based on relative price as well as nominal price does not matter due to the reason that equilibrium will not be disturbed if both nominal income and all nominal prices rise proportionally (e.g., neutrality of money and dichotomy between real factors and nominal factors). Maximum utility hypothesis is the foundation of natural rate unemployment hypothesis because labor supply is supposed not to change when market nominal prices and nominal aggregate income change proportionally. If labor supply is built on maximum utility hypothesis, then labor supply should relates to nominal wage instead of real wage. Since real wage is equal to nominal wage divided by price level while both nominal wage and price level are dependent variable in general equilibrium model, real wage is definition which should play no role in economic theory. For example, natural rate unemployment hypothesis is false because Friedman did not recognize that decision making (e.g., maximum utility hypothesis and labor supply) is based on nominal price instead of real wage. Besides, the role of real wage in natural rate unemployment hypothesis is not only independent variable to determine labor demand and labor supply in the sense of ex-post and ex-ante respectively in Friedman's second idea cited in section 2 but also dependent variable determined by labor supply and labor demand in labor market endogenously when Friedman used both excess demand for labor and excess supply of labor to predict the relationship between real wage and unemployment. It is worth noting that I did not discuss real wage when I argued that natural rate unemployment hypothesis is false in section 2 because the concept of nominal price regime, which is the sufficient condition for decision making (e.g., maximum utility hypothesis), and the concept of real wage in terms of purchasing power, which is definition inferred from nominal wage and inflation rate, are too complicate to be clarified by couple paragraphs.

Is it possible that there is an economy in which labor market determines real wage in terms of a bundle of real goods instead of purchasing power while other markets determine nominal price so that real wage in terms of a bundle of real goods works because we know market prices and inflation rate so as to convert real wage in terms of a bundle of real goods into nominal wage? Firms need nominal wage to calculate total cost and then sets nominal product price for sale. But firms do not know nominal wage before firms work out supply curve and set nominal product price because labor market determines real wage in terms of real goods and real wage in term of real goods cannot be converted into nominal wage before firms set nominal prices. Consequently, firms cannot count on real wage in terms of real goods to set nominal product price so that we cannot determine inflation rate in general equilibrium model although real wage in terms of real goods is determined in labor market already. In short, it is circular reasoning that we need to know nominal wage before we determine inflation rate but we have 
to know nominal price and inflation rate before we convert real wage in terms of real goods into nominal wage in terms of purchasing power under the assumption that labor market determines real wage in terms of real goods. Note that it is expected nominal wage instead of real wage in terms of purchasing power if we use a bundle of real goods and expected prices to convert real wage in terms of real goods into nominal wage. In this case, we still need inflation rate in the sense of ex-post to convert expected nominal wage into real wage in terms of purchasing power although firms use expected nominal wage to set selling price. Thus, real wage in terms of purchasing power is still definition. Besides, we do not know that expected nominal wage makes labor market converge or diverge as well as selling price based of expected nominal price drive economy to converge or diverge.

Similarly, real interest rate is definition because real interest is equal to nominal interest rate minus inflation rate while ex-post market nominal interest rate is dependent variable due to reason that credit markets determine ex-post market nominal interest rates as well as inflation rate is dependent variable due to the reason that product markets determine ex-post market nominal prices. Thus, real interest rate is inferred from ex-post inflation rate and ex-post nominal interest rate by arithmetic computation as income velocity is definition inferred from ex-post aggregate income and ex-post quantity of money. If real interest rate depends on anticipated inflation rate and we form price expectation endogenously, real interest rate is definition because anticipated inflation rate is dependent variable. If price expectation is given exogenously, real interest rate is still definition because ex-post nominal interest rate is always dependent variable. Consequently, Phelps (1967) is false because Phelps mistook real interest rate for independent variable in his growth model to explain Phillips curve.

To summarize, relative price, real interest rate and real wage are all definitions in general equilibrium model so that all real prices are forbidden to be independent variable in general equilibrium model.

\section{Microeconomic Model of Wage Phillips Curve}

Cost function depends on certain number of labors, certain volume of capital stock and production function while we ignore intermediate inputs. The quantity of product that the firm plans to produce under certain market demand for product and certain cost function determines the quantity of labor that the firm plans to employ. Thus, the quantity of labor that the firm needs depends on market demand function of product, capital stock, the price of capital utilization and market wage. Capital stock and quantity of labor regard production function. Wage and price of capital utilization relate to cost.

When the firm is so small that the firm does not have influence on market wage (i.e., $\frac{\partial \mathrm{w}}{\partial N}=0$ because market wage is a constant for the firm), we would like to know how many labors that the firm plans to employ under the assumption that the volume of product moves along a given product demand curve and the objective of the firm is maximum return rate on capital described by equation (1).

$$
\begin{gathered}
\frac{\partial P}{\partial Q} \frac{\partial Q}{\partial N} Q+P \frac{\partial Q}{\partial N}-w=0 \\
\frac{\partial N}{\partial Q}=\frac{P\left(1+\frac{1}{\eta}\right)}{w}>0
\end{gathered}
$$

Equation (11) means that the firm keeps hiring new employee until the market wage given exogenously is equal to marginal value of marginal labor productivity. Equation (12) tells us the change in number of employee while output moves along a given product demand curve and other things are equal (e.g., capital stock and market wage are given exogenously). When output moves along a given product demand curve, $\frac{\partial N}{\partial Q}$ is the output effect on labor demand curve under fixed wage and capital, which is reciprocal of marginal product of labor. Equation (12) is greater than zero because firms refuse to increase supply of output by moving along product demand curve if marginal revenue is less than zero. Equation (12) does not represent the output effect arising from shifting in demand curve of product. Besides, there is no any information about the total number of employee in equation (11) and (12). By equation (2) and (11), we get

$$
P Q=P\left(1+\frac{1}{\eta}\right) \frac{\partial Q}{\partial N} N+P\left(1+\frac{1}{\eta}\right) \frac{\partial Q}{\partial K} K=w N+\gamma K
$$




$$
N=\frac{P Q-\gamma K}{w}
$$

Equation (13) means that total sales revenue is distributed into either wage reward to employees or return on capital. Where $\gamma$ is the price that pays for capital utilization, which is equal to depreciation rate of capital plus profit rate. Economists usually believe that wage, price of product, quantity of product, return rate on capital and volume of capital are all independent variables to affect number of employee. Virtually, equation (14) represents the mathematic mapping among these five variables while employment $(N)$ is effect and maximum return rate on capital hypothesis (equation (1)), demand function of product represented by $P Q$, cost function represented by $\gamma K+w N$ and production function represented by $Q(K, N)$ are cause. Thus, it is too simple to be true that aggregate income (i.e., value of total current output) determines volume of employment in macroeconomics and wage determines number of employee in microeconomics.

Ting (2017b) used $P Q$ and $(P-c) Q$ to represent two parallel product demand curves where $c$ is positive constant. When product demand curve shifts leftward from $P Q$ toward $(P-c) Q$, we get

$$
\begin{aligned}
& \operatorname{Max} \frac{(P-c) Q-w_{C} N_{C}}{K_{C}} \\
& (P-c) Q=(P-c)\left(1+\frac{1}{\eta}\right) \frac{\partial Q}{\partial N_{c}} N_{c}+(P-c)\left(1+\frac{1}{\eta}\right) \frac{\partial Q}{\partial K_{c}} K_{c}=w_{c} N_{c}+\gamma_{c} K_{c} \\
& Q=\frac{w_{c} N_{c}+\gamma_{c} K_{C}}{P-c} \\
& \frac{\partial Q}{\partial c}=\frac{-\left(w_{c} N_{c}+\gamma_{c} K_{c}\right)}{(P-c)^{2}}<0 \\
& N_{c}=\frac{(P-c) Q-\gamma_{c} K_{c}}{w_{c}} \\
& \frac{\partial N_{c}}{\partial c}=\frac{\partial \frac{(P-c) Q-\gamma_{c} K_{c}}{w_{c}}}{\partial c}=\frac{\partial \frac{(P-c) Q-\gamma_{c} K_{c}}{\left(\frac{\partial P-c}{\partial Q} Q+(P-c)\right) \frac{\partial Q}{\partial N_{c}}}}{\partial c} \\
& =\frac{\left.-Q\left(\frac{\partial P-c}{\partial Q} Q+(P-c)\right) \frac{\partial Q}{\partial N_{c}}\right)+\frac{\partial Q}{\partial N_{c}}\left\{\left(\frac{\partial P-c}{\partial Q} Q+(P-c)\right) \frac{\partial Q}{\partial N_{c}} N_{c}\right\}}{\left\{\left[\frac{\partial P-c}{\partial Q} Q+(P-c)\right] \frac{\partial Q}{\partial N_{c}}\right\}^{2}} \\
& =\frac{-Q+\frac{\partial Q}{\partial N_{C}} N_{C}}{\left(\frac{\partial P-c}{\partial Q} Q+(P-C)\right) \frac{\partial Q}{\partial N_{C}}}<0 \\
& \frac{\partial w_{c}}{\partial c}=\frac{\partial\left(\frac{\partial P-c \partial Q}{\partial Q \partial N_{C}} Q+(P-c)\right) \frac{\partial Q}{\partial N_{C}}}{\partial c}=-\frac{\partial Q}{\partial N_{C}}<0 \\
& \frac{\partial \frac{Q}{N_{C}}}{\partial N_{C}}=\frac{\frac{\partial Q}{\partial N_{C}} N_{c}-Q}{N_{c}{ }^{2}}<0 \text { if } \frac{\partial Q}{\partial N_{c}}<\frac{Q}{N_{C}}
\end{aligned}
$$

Let $N_{c}$ and $K_{c}$ be the number of labor and the volume of capital that the firm plans to employ respectively when product demand curve shifts leftward ( $c>0$ ). If $c=0$, then equation (16) and equation (13) are identical. Equation (13) and equation (16) describe factor income distribution when the firm reaches equilibrium. Equation (18) demonstrate that output will fall if product demand curve shifts leftward and output will rise if product demand curve shift rightward. Equation (20) is the change in number of employee caused by shifting in demand curve of product (i.e., change in $c$ ), which is different from the change in number of workers caused by moving along a given product demand curve, $\frac{\partial N}{\partial Q}$. In other words, equation (20) means that labor demand curve shifts toward the same direction as product demand curve shifts because employment increases (decreases) while wage does not change (i.e., labor demand curve shifts) due to rightward (leftward) shifting in product demand curve. Equation (22) guarantees that equation (20) is negative because marginal product of labor diminishes so that 
average product of labor is always larger than marginal product of labor. In equation (20), the negative relationship between $c$ and $N_{c}$ (employment) means that employment decreases when product demand curve shift leftward $(P-c$ and $c>0)$ and employment increase when product demand curve shifts right $(P+c$ and $c>0$ ). It coincides with the employment theory in macroeconomics that employment increases (decreases) if aggregate income rises (falls).

Equation (21) shows that the wage, which firms intend to pay, falls (rises) when product demand curve shifts leftward (rightward). It implies that income effect (i.e., shifting in product demand curve) makes ex-post output, ex-post employment and ex-post wage rise and fall simultaneously in microeconomics under the circumstances of shifting in product demand curve inter-periods. This conclusion is consistent with pro-cyclical co-movements that ex-post inflation rate, ex-post aggregate income, ex-post employment and ex-post wage are positively correlated each other during business cycle so that we observe negative slope Phillips curve. Thus, microeconomics and macroeconomics are analogous. In other words, there is no causal relation between ex-post wage and ex-post unemployment (i.e., wage Phillips curve) in microeconomics although ex-post unemployment and ex-post wage is negatively correlated in the sense of statistics significantly. Thus, I prove that wage Phillips curve is correlation instead of causal relation by firm theory in microeconomics. In addition, equation (21) shows that the change in wage depends on labor productivity when product demand curve shifts. This conclusion is consistent with the rise in both wage and marginal productivity of labor during the recovery between 1934 and 1939 discussed in Ting (2017b).

Price substitution effect is the corner stone of microeconomics to analyze economic activity based on the assumption that other things are equal except price. That is the reason why microeconomics usually does not concern income effect and output effect so that microeconomics was not able to handle business cycle because business cycle regards change in total output in terms of aggregate income. Since macroeconomics used to concern unemployment caused by change in aggregate income (i.e., income effect and output effect) while microeconomics used to deal with wage substitution effect on employment, it misleads us to believe that macroeconomics and microeconomics are irrelevant and opposite, e.g., positive relationship between wage and employment in macroeconomics versus negative relationship between wage and employment on labor demand curve in microeconomics. In fact, microeconomics and macroeconomics are consistent because we can derive positive relationship between wage and employment from equation (20) and (21) if we introduce income effect and output effect, caused by shifting in product demand curve, on employment and wage into firm theory.

This paper predicts that samples, which we collect from fluctuation of aggregate income, usually have the negative relationship between wage and unemployment except supply shock because product demand curve shifts during business cycle as well as samples, which we collect from stagnant aggregate income, usually have positive relationship between wage and unemployment because both demand curve of product and labor demand curve almost do not shift so that wage substitution effect will be apparent (e.g., change in the ratio of capital to labor) if wage fluctuates.

\section{Macroeconomic Model of Phillips Curve}

Ting (2011) derived two equations, which regard market interdependence, from individual economic agents. One equation regards the market interdependence between output sector and loan sector. The other refers to the relationship between input sector and loan sector. Each sector is composed of all markets that deal with goods have the same essential characteristics. For example, output sector is composed of all markets in which each market deals with a particular product produced in current period and loan sector is composed of all credit markets in which each credit market transacts a particular type borrowing and lending (e.g., bank loan and bond) in current period.

$$
\begin{gathered}
\left(Y^{s}-Y^{d}\right)+(1-r)\left(L^{d}-L^{s}\right)=0 \\
w\left(N^{s}-N^{d}\right)+\gamma\left(K^{s}-K^{d}\right)+(1-r)\left(L^{d}-L^{s}\right)=0
\end{gathered}
$$

Equation (26) and (27) correspond to equation (11) and (15) in Ting (2011) respectively. Where $s, d, Y, L, N$, $K, w, \gamma$ and $r$ are supply, demand, aggregate income, loan, labor, capital, wage, return rate on capital and interest rate respectively. Borrowing and lending are equivalent to demand for loan and supply of loan respectively. $Y^{s}\left(Y^{d}\right)$ is equivalent to the idea of total output produced currently in the sense of supply (in the sense of demand). Patinkin (1976, p.85-6) expressed that Keynes (1936) defined aggregate income based on not only supply side named aggregate supply price but also demand side named aggregate proceeds or aggregate demand price in chapter 3 . The concept of aggregate income in chapter 3 of General Theory is ex-ante while 
$Y=C+I$ and $Y=C+S$, the definition of aggregate income in chapter 6 of General Theory, are ex-post. Keynes (1936, p.25) wrote "the expected proceeds are greater than the aggregate supply price...there will be an incentive to entrepreneurs to increase employment..." In this paper, "the expected proceeds" corresponds to $Y^{d}$ and "aggregate supply price" is equivalent to $Y^{s}$. Thus, economy expands when $Y^{d}>Y^{s}$ as Keynes addressed above.

Equation (26) and (27) predict that output sector, input sector and loan sector are simultaneously either in excess demand (expansion) or in excess supply (contraction) in current period. In other words, aggregate income, price level, employment, wage, volume of loan and interest rate are all dependent variables in Ting's model and these six dependent variables form pro-cyclical co-movements (i.e., these six dependent variable are positively correlated each other) in the sense ex-post. Both boom (e.g., all sectors are in excess demand so that every sector expands) and glut (e.g., all sectors are in excess supply so that every sector contracts) are essential characteristics of business cycle while boom and glut induce pro-cyclical co-movements (e.g., Phillips curve and Gibson's paradox). Thus, there is absolutely no trade-off between wage rate and unemployment rate as well as inflation rate and unemployment rate not only in the long run but also in the short run as Friedman (1977) conjectured that economists misinterpreted correlation for causal relation.

Ting (2011) assumed that all economic agents are self-employee so that equilibrium in output markets implies equilibrium in input markets. In other words, Ting (2011) did not show the possibility that some non-friction unemployment cannot be eliminated by expansionary policy. If a general equilibrium model generates Phillips curve in the sense of pro-cyclical co-movement but omits persistent unemployment, this general equilibrium model is incomplete and unsound because persistent unemployment is an important phenomenon of business cycle. Since firms employ labor and capital in real world, I modify the model in Ting (2011) in order to demonstrate the possibility of persistent unemployment.

Since $Y^{S}$ regards firms' production plan in the sense of aggregation, $Y^{s}$ tell us how many units of input factors firms actually plan to employ. $Y^{d}$ implies how many unit of input factors firms need to employ if market demand for product is fitted by market supply. Thus, equation (27) is replaced by equation (28) because I exclude both labor supply and capital supply from the model in Ting (2011).

$$
\left(w\left(N_{f}^{d}-N_{m}^{d}\right)+\gamma\left(K_{f}^{d}-K_{m}^{d}\right)\right)+(1-r)\left(L^{d}-L^{s}\right)=0
$$

Let subscript $f$ and $m$ represent firms' demand for input factors and markets' demand for input factors respectively. In this paper, there are two demand functions for input factors. One is the volume of input factor that economy needs in order to fit in aggregate demand for output $\left(Y^{d}\right)$ so that $N_{m}^{d}$ and $K_{m}^{d}$ in equation (28) are identical to $N^{d}$ and $K^{d}$ in equation (27) respectively. The other is the volume of input factor that entrepreneurs plan to employ based of their plan to produce certain volume of output, $Y^{s}$. Let $N_{f}^{d}$ be demand for labor derived from $Y^{s}$ by entrepreneurs. Thus, $N^{s}$ (labor supply) in equation (27) is replaced by $N_{f}^{d}$ (labor demand of the firm) in equation (28). Since supply of product also tells entrepreneurs the utilization rate of the capital controlled by firms, I substitute $K_{f}^{d}$ (firm's demand for capital) in equation (28) for $K^{s}$ supply of capital in equation (27), too. If $Y^{s}>Y^{d}$ and $L^{s}>L^{d}$, it implies that firms employ more input factors than markets can carry $\left(N_{f}^{d}>N_{m}^{d}\right.$ and $\left.K_{f}^{d}>K_{m}^{d}\right)$. Consequently, entrepreneurs will decide to lay off input factors (i.e., shift supply curve leftward) due to excess supply of outputs. If $Y^{d}>Y^{s}$ and $L^{d}>L^{S}$, the volume of input factors, which entrepreneurs employ, is less than the volume of input factors, which $Y^{d}$ needs, so that employment will increase. Since supply of input factor disappears in aggregate budget constraint when self employee is replaced by hiring, equation (28) represents real world. Then, I reach a crucial conclusion that equilibrium of output sector (i.e., $Y^{s}=Y^{d}$ ) does not imply the equilibrium of input sector (i.e., full employment which is equivalent to $N^{s}=N_{f}^{d}=N_{m}^{d}$ ) due to the reason that both supply output and demand for output are independent of supply of labor. It is worth noting that $L^{d}-L^{s}$ (excess demand for loan and excess supply of loan) indicates not only output growth but also input growth so that equation both (27) and (28) coincide with the statement in Bernanke and Lown (1991, p.224) that "employment growth is strongly related to current loan growth".

There is another reason to support the argument above that supply of labor should be excluded from equation (28). Ting (2011) showed that the Keynesian consumption function is $C^{d}=b Y^{s}$ instead of $C=b Y$ because the former is ex-ante and the latter is ex-post. According to Clower (1965), $C^{d}=b\left(w N^{s}+\gamma K^{s}\right)$ is the notional demand for consumption because it means the amount of consumption that $N^{s}$ labors are willing to spend in consumption if $N^{s}$ labors are employed. Since $N^{s}$ may not be equal to the number of labor that entrepreneurs plan to employ, $C^{d}$ is not effective if $C^{d}$ depends on labor supply. But both $w N_{f}^{d}$ and $\gamma K_{f}^{d}$ are not only the ex-ante factor income that households will receive but also entrepreneurs plan to pay in the future. Thus, 
$Y^{s}=w N_{f}^{d}+\gamma K_{f}^{d}$ is the effective factor income on which effective consumption depends. Thus, $C^{d}=$ $b\left(w N_{f}^{d}+\gamma K_{f}^{d}\right)$ is Clower's constrained demand because it means the amount of consumption that $N_{f}^{d}$ labors, who will be employed by firms in the sense of ex-ante, are willing to and affordable to spend effectively.

There are two crucial implications derived from equation (28). Although labor supply is not included in the equation (28), pro-cyclical co-movements stand as Ting (2011) stated because output influences on demand for input while supply of input factor does not affect demand for output through consumption due to the reason that some input factors may not be employed. Second, equilibrium of output sector (i.e., $Y^{s}=Y^{d}$ ) does not imply that labor market is in equilibrium (i.e., full employment) in equation (26) and (28) but equation (26) and (27) does. By equation (28), it is possible that we are not able to handle cyclical unemployment by expanding aggregate demand $\left(Y^{d}\right)$ immediately because $Y^{s}$ does not increase (i.e., employment does not increase) so that consumption is sluggish and unemployment is more persistent than we expect. For example, firms reduce inventory to fit increase in demand for goods when $Y^{d}>Y^{s}$.

\section{Keynesian Unemployment Equilibrium and Involuntary Unemployment}

Keynes (1936, p. 26) addressed "Thus Say's law, that the aggregate demand price of output as a whole is equal to its aggregate supply price for all volume of output, is equivalent to the proposition that there is no obstacle to full employment." In Keynes' mind, full employment is the volume of employment corresponding to $Y^{d}=Y^{s}$. When $Y^{s}=Y^{d}$ but $N^{s}>N_{m}^{d}$, we get Keynes unemployment equilibrium interpreted by Leijonhufvud (1968, p.86) and natural rate unemployment because aggregate income is in equilibrium but labor market is in disequilibrium. Since $Y^{s}=Y^{d}$ does not imply full employment $\left(N^{s}=N^{d}\right)$ in equation (28), Keynes was wrong. If $Y^{s}=Y^{d}$ is static equilibrium (i.e., net aggregate investment is equal to zero so that $Y_{t}^{s}=Y_{t+1}^{s}$ ), we cannot reduce unemployment immediately by increase in $Y_{t+1}^{d}$ (e.g., government expenditure) due to the reason that $Y_{t+1}^{s}$ does not increase and $N_{f, t+1}^{d}$ depends on $Y_{t+1}^{s}$ instead of $Y_{t+1}^{d}$. If $Y_{t}^{s}=Y_{t+1}^{s}, C_{t}^{d}=C_{t+1}^{d}$ because both ex-ante factor income and ex-ante employment (i.e., labor demand) do not increases. Thus, expansionary policy is usually less effective than we wish. Since business cycle is the process of deviation from and restoration to equilibrium if Keynesian unemployment equilibrium is static (i.e., both aggregate demand curve and aggregate supply curve do not shift), the unemployment under static Keynesian unemployment equilibrium is equivalent to natural rate of unemployment due to return to its former level as Friedman (1968) stated. It is worth noting that growth theory (e.g., Domar (1947)) took care of business cycle if Keynesian unemployment equilibrium is dynamic equilibrium (e.g., net investment is greater than zero so that $Y_{t+1}^{S}>Y_{t}^{S}$ due to rightward shifting in aggregate supply curve).

Modigliani (1944) stated in section 16 that "There is one case in which the Keynesian theory of liquidity preference is sufficient by itself to explain the existence of under-employment equilibrium without starting out with the assumption of rigid wage." Consider a non-credit barter economy in which firms employ labors. It is possible that $Y^{s}=Y^{d}$ and $N^{s}>N_{m}^{d}$ while there is no money, credit and liquidity preference. Thus, Keynesian unemployment equilibrium is independent of liquidity preference in this paper. Besides, Ting (2017b) demonstrated that wage rigidity would result from supply of product and demand for product endogenously rather than union and minimum wage law exogenously so that wage rigidity is not the sufficient condition for Keynesian unemployment equilibrium.

Keynesian unemployment equilibrium and natural rate unemployment are very close conceptually even Friedman (1987, p. 18) wrote "The concept of "underemployment equilibrium" has been replaced by "natural rate of employment". Although both Keynesian unemployment equilibrium and natural rate of unemployment leads to the same conclusion that there is certain volume of unemployment which cannot be eliminated by expansion of aggregate demand $\left(\Delta Y^{d}\right)$, Keynesian unemployment equilibrium is completely different from of natural rate unemployment. In this paper, the cause of Keynesian unemployment equilibrium is hiring and Phillips curve does not relate to Keynesian unemployment equilibrium. Friedman (1968) did not tell us the cause of natural rate unemployment but argued that the shifting of short run inflation Phillips curve is caused by natural rate unemployment.

Keynes (1936, p. 15) wrote "Men are involuntarily unemployed if, in the event of a small rise in the price of wage-goods relatively to money wage, both the aggregate supply of labor willing to work for the current money-wage and the aggregate demand for it at that wage would be greater than the existing volume of employment." We observed that the money wage rate during boom were higher than or equal to the money wage rate during recession but the number of employment during boom was greater than the number of employment during recession. The difference in volume of employment between boom and recession coincides with what 
Keynes wrote that "the aggregate demand for it at that wage would be greater than the existing volume of employment". Since involuntary unemployment refers to the change in volume of unemployment under given wage, involuntary unemployment regards the increase in unemployment that is caused by the leftward shifting in labor demand curve. Thus, involuntary unemployment is different from the unemployment caused by deviation away from labor market equilibrium while both labor supply curve and labor demand curve are fixed. Since involuntary unemployment depends on shifting in product supply curve, product demand curve and labor demand curve cyclically, we need expansionary policy to cure involuntary unemployment by rightward shifting in product demand curve to induce rightward shifting in labor demand curve under the circumstance that firms own idle capital stock to increase supply of output.

If both labor supply curve and labor demand curve are given and the number of unemployment increases, wage must rise. Under this circumstance, there is no involuntary unemployment because involuntary unemployment required that wage should not rise as well as unemployment should increase. If wage substitution effect (i.e., moving along a given labor demand curve due to change in wage) dominates output effect (i.e., shifting in labor demand curve), the decrease in money wage between 1929 and 1933 was impossible to be accompanied with aggravation of unemployment. Thus, the rise in unemployment between 1929 and 1933 was involuntary unemployment caused by insufficient demand for goods because wage was decreasing instead of rising. In other words, it is false that unemployment increased during Great Depression because natural rate unemployment rose and some labors searched new job instead of work.

When product demand curve shifts leftward, Ting (2017b) demonstrated that firms have to shift their supply curve leftward in order to produce less than before even the market price is the same as before (i.e., price rigidity). To lay off labors implies that labor demand curve shifts leftward because firms employ less worker than before even market wage is the same as before. To lay off labors also implies that product supply curve shifts leftward because production scale decreases. Lay off is the qualitative evidence for shifting in labor demand curve and product supply curve. For example, employment decreases under wage rigidity (i.e., firms employ less labors than before under given wage). In this case, we have to attribute the increase in unemployment during recession to the decrease in $Y^{d}$ instead of wage rigidity. If wage rises and unemployment deceases (e.g., 1934-1939 in U.S.), we assure that labor demand curve shifts rightward. I reach a crucial conclusion that involuntary unemployment is consistent with wage Phillips curve because wage and involuntary unemployment is negatively correlated. Besides, the price rigidity between 1934 and 1939 implies that both product supply curve and product demand curve in the sense of aggregation shift because quantity of total output (i.e., GDP) grows while inflation rate is fixed. In short, shifting in both supply curve and demand curve is the corner stone of business cycle theory.

Lucas (1978, p. 354) wrote "In summary, it does not appear possible, even in principle, to classify individual unemployed people as either voluntarily or involuntarily unemployed depending on the characteristics of the decision problems they face." I believe that Lucas criticized Keynes's involuntary unemployment from the view point of decision making of an individual worker in the theory of labor supply because Lucas used changes in labor supply to explain why aggregate income fluctuates (e.g., Lucas \& Rapping, 1969). When labors substitute leisure for work, $Y^{S}$ declines. In this case, it is possible that aggregate income decreases but wage increases (i.e., labor market is in excess demand) and product markets are in excess demand because job searchers have to consume in order to live. Thus, $C^{d}$ and $Y^{d}$ may not decrease when unemployment increases due to job search. Black Death is an example of income fluctuation caused by decrease in labor supply. Broadberry et.al (2012) found that real wage rose during Black Death in the thirteenth century while both population and GDP declined tremendously. Lucas' unemployment theory does not deny Keynes' idea of involuntary unemployment because reduction in aggregate income caused by reduction in labor supply does not imply general glut in product markets and rise in unemployment rate, which are two essential characteristics of recession.

\section{Conclusion Remarks}

The contribution of this paper to economics is methodology. I demonstrate that we are not permitted to construct economic theory on variables, which are determined by market supply and market demand endogenously, because those variables are dependent variable and dependent variable cannot explain anything. The strong correlation between two dependent variables (e.g., price and quantity) is nonsense because there is no causal relation between two dependent variables. For example, New Keynesian economics argued that low (high) interest rate causes low (high) inflation rate so that we observed flat inflation Phillips curve after 2008 due to the reason that Quantity Easing induced low interest rate. Since interest rate is the price of borrowing and lending determined by market demand for loan and market supply of loan while inflation rate is the average price of GDP determined by market demand for total current output and market supply of total current output, equation 
(26) predicts that the relationship between ex-post interest rate and ex-post inflation rate is positive correlation of two dependent variables, not causality. As Phillips curve, New Keynesian economics misinterprets the pro-cyclical co-movements of ex-post interest rate and ex-post inflation rate (i.e., Gibson's paradox) for causal relation to construct model. The microeconomic model in section 4 and the macroeconomic model in section 5 show that wage, employment, inflation rate, GDP, interest rate and volume of loan are six dependent variables determined by market supply and market demand in each market endogenously. Thus, there are fifteen meaningless combinations of two dependent variables and each combination induces an apparent correlation by the analysis of time series, especially short term time series. For examples, wage and employment (i.e., wage Phillips curve), inflation rate and GDP, interest rate and volume of loan, wage rate and inflation rate, interest rate and inflation rate (i.e., Gibson's paradox) and inflation rate and employment rate (i.e., inflation Phillips curve) are all meaningless correlation in economics theoretically. Besides, Fisher's exchange equation is also a case of meaningless correlation because both quantity of money, which is determined by money supply and money demand, and nominal GDP, which is determined by supply of total current output and demand for total current output, are dependent variable in macroeconomics.

Finally, economists have not established the true methodology to practice and evaluate economic policy yet. Since inflation rate, interest rate, unemployment rate, growth rate of GDP and quantity of money are all dependent variables, they are not instruments to control economy but targets of economic policy. Targets may not conflict each other (e.g., trade-off between inflation rate and unemployment rate is wrong) because targets are all dependent variables. We can achieve targets if we control independent variables (i.e., instruments) correctly and targets assigned by us are available choice in general equilibrium model. Let's study several cases. First, Ting (2011) showed that borrowing and lending is independent variable so that we are able to affect interest rate, employment and aggregate income if we can control both supply of loan and demand for loan. Since the monetary policy of Federal Reserve Bank affects loan market, Federal Reserve Bank is influential. But it is wrong that Federal Reserve Bank try to affect economy by controlling interest rate in order to peg GDP growth rate, inflation rate and unemployment rate because interest rate is dependent variable, not instrument. Second, it is false that inflation rate is instrument and unemployment rate is target. Third, government expenditure and tax rate are instrument because government expenditure and tax rate are usually exogenous so that fiscal policy works except that Keynesian unemployment equilibrium is static.

Lucas (1976) criticized econometric policy evaluation because parameters drift due to the reason that economic agents change their behavior in order to respond to change in economic policy (e.g., parameter drifting of Phillips curve discussed in section 5.3 of Lucas (1976)). Since economists have built economic theory on dependent variable for centuries (e.g., quantity theory of money and stabilization policy based on Phillips curve), economists have misinterpreted change in meaningless correlation between two dependent variables for parameter drifting (i.e., change in behavior of economic agents which is independent behavior). Thus, I conclude that the true problem of econometric policy evaluation is that economists construct the contemporary economic theory and econometric model on relationships between dependent variables and dependent variables instead of relationships between independent variables and dependent variables.

\section{References}

Bernanke, B., \& Lown, C. (1991). The Credit Crunch (pp. 205-247). Brookings Papers on Economic Activity.

Bhattarai, K. (2016). Unemployment - Inflation Trade-offs in OECD Countries. Econometric Modelling, 58, 93-103. https://doi.org/10.1016/j.econmod.2016.05.007

Bils, M. (1985). Real wages over the business cycle: Evidence from panel data. Journal of Political Economy, 93, 666-689. https://doi.org/10.1086/261325

Bordo, M., Lane, J., \& Redlish, A. (2004). Good versus Bad Deflation: Lesson from the Gold Standard Era. NBER working paper No. 10329. https://doi.org/10.3386/w10329

Borio, C., Erdem, M., Filrardo, A., \& Hofman, B. (2015). The cost of Deflation: A historical perspective. Quarterly Review.

Broadberry, S., Campell, B., Klein, A., Overton, M., \& Leeuwen, B. V. (2012). British Business Cycle, 1270-1870. Retrieved from http://www.lse.ac.uk/econmicHistory/pdf/broadberry/britishCycle4a.pdf

Clower, R. W. (2005). The Keynesian Counter-Revolution: A Theoretical Appraisal. In F. H. Hahn, \& F. Brechling (Eds.), The Theory of Interest Rates (Chapter 5, pp. 103-125). International Association Series, Macmillan.

Coibion, O., \& Gorodnichenko, Y. (2015). Is the Phillips Curve Alive and Well After All? Inflation Expectations 
and The Missing Disinflation. American Economic Journal: Macroeconomics, 7, 197-232. https://doi.org/10.1257/mac.20130306

Domar, E. (1947). Expansion and Employment. American Economic Review, 7, 34-55.

Dreger, C., \& Wolters, J. (2011). Money and inflation in the euro area during financial crisis. DIW Berlin Discussion Paper, No. 1131. https://doi.org/10.2139/ssrn.1869850

Friedman, M. (1968). The Role of Monetary Policy. American Economic Review, 58, 1-17.

Friedman, M. (1974). Monetary Correction: A Proposal for Escalation Clauses to Reduce the Cost of Ending Inflation. Institute of Economic Affair, Occasional Paper No. 41.

Friedman, M. (1977). Inflation and Unemployment. Journal of Political Economy, 85, 451-472. https://doi.org/10.1086/260579

Friedman, M. (1987). Quantity Theory of Money. In J. Eatwell, M. Milgate, \& P. Newman (Eds.), The New Palgrave: A Dictionary of Economomics (Vol. 4, pp. 3-20). New York: Stockton Press, and London: Macmillan.

Fuhrer, J., \& Schuh, S. (1998). Beyond Shocks: What Causes Business cycles? An Overview. New England Economic Review, 3-24.

Galí, J. (n. d.). Hysteresis and the European unemployment problem revisited: Inflation and Unemployment in Europe (pp. 53-79). ECB Forum on Central Banking, European Central Bank.

Goldfeld, S. (1976). The Case of Missing Money. Brookings paper on Economic Activity (pp. 683-739). https://doi.org/10.2307/2534372

Gorden, R. (2013). The Phillips Curve is Alive and Well: Inflation and the NAIRU During the Slow Recovery. NBER Working Paper No. 19390. https://doi.org/10.3386/w19390

Granger, C. (2003). Time Series Analysis, Cointegration, and Applications. Nobel Lecture.

Granger, C., \& Jeon, Y. (2009). The evolution of the Phillips curve: A modern time series viewpoint. Economica, 78, 51-66. https://doi.org/10.1111/j.1468-0335.2009.00839.x

Guido, B., \& Eliana, V. (2016). Has the wage Phillips curve changed in the Euro area? Banca D'Italia occasional paper No. 355. Retrieved from http:/www.bancaditalia.it

Hoover, K. (2013). Identity, Structure, and Causal Representation in Scientific Models. In C. Hsiang-Ke (Ed.), Mechanism and Causality in Biology and Economics. https://doi.org/10.1007/978-94-007-2454-9_3

Leijonhufvud, A. (1968). On Keynesian Economics and the Economics of Keynes. New York: Oxford University Press.

Lucas, R. (1972). Unemployment in the Great Depression: Is There a Full Explanation? Journal of Political Economy, 80, 186-191. https://doi.org/10.1086/259872

Lucas, R. (1976). Econometric Policy Evaluations: A Critique. In K. Brunner, \& A. H, Meltzer (Eds.), The Phillips and Labor Markets (pp. 19-46). Carnegie-Rochester Conference Series on Publlic Policy, Amsterdam: North Holland.

Lucas, R. (1977). Understanding Business Cycles. In K. Brunner, \& A. H. Meltzer (Eds.), Stabilization of the domestic and International Economy (pp. 7-29). Amsterdam: North-Holland Publishing Company. https://doi.org/10.1016/0167-2231(77)90002-1

Lucas, R. (1978). Unemployment Policy. American Economic Review, 68, 353-357.

Lucas, R. (1980). Methods and Problems in Business Cycle Theory. Journal of Money, Credit, and Banking, 12, 696-715. https://doi.org/10.2307/1992030

Lucas, R., \& Nicolini, J. P. (2015). On the Stability of Money Demand. Working Paper No. 718, Federal Reserve Bank Minneapolis. https://doi.org/10.1016/j.jmoneco.2015.03.005

Lucas, R., \& Rapping, L. (1969). Real Wages, Employment, and Inflation. Journal of Political Economy, 77, 721-54. https://doi.org/10.1086/259559

Lucas, R., \& Sargent, T. (1979). After Keynesian Macroeconomics. Quarterly Review, 1-16.

Martyna, M., \& Gómez, V. (2012). Cyclicality of Real Wage in the USA and Germany: New Insights from Wavelet Analysis. Retrieved from http://www.Coin.wne.vw.edu.pl/wien/papers-2012/Marczak.pdf 
Messina, J., Strozzi, C., \& Turunen, J. (2009). Real wage over the business cycle: Oecd evidence from the time and frequency domains. European Central Bank, working paper series, No. 1003/2009. https://doi.org/10.1016/j.jedc.2008.11.005

Neely, C. (2010). U. U. History Experience with Deflation. Economic Synopses, Federal Reserve Bank, St. Louis.

Omerčević, E., \& Nuroğlu, E. (2014). Phillips and Wage Curves: Empirical Evidence from Bosnia and Hevzegovina. Economics Research International. https://doi.org/10.1155/2014/436527

Patinkin, D. (1976). Keynes' Monetary Thought. Duke University press.

Phelps, E. (1967). Phillips Curves, Expectations of Inflation and Optimal Unemployment over Time. Economica, 34, 254-281. https://doi.org/10.2307/2552025

Phillips, W. (1958). The Relation between Unemployment and the Rate of Change of Money Wage Rates in United kingdom, 1861-1957. Economica, 25, 283-299.

Rothbard, M. (2002). History of Money and Banking in the United States: The Colonial Era to World War II. edited with An Introduction by Joseph T. Salrno.

Samuelson, P., \& Solow, R. (1960). Analytical aspects of anti-inflation Policy. American Economic Review, 50, $177-94$.

Sims, C. (n. d.). Money, Income, and Causality. American Economic Review.

Teles, P., \& Zhou, R. (n. d.). A Stable Money Demand: Looking for the Right Monetary Aggregate. Economic Perspective, 29, 50-63.

Thornton, D., \& Batten, D. (1985). Lag-Length Selection and Tests of Granger Causality between Money and Income. Journal of Money, Credit and Banking, 17, 164-178. https://doi.org/10.2307/1992331

Ting, C. C. (2010). The Optimal Size of the Firm and Growth Theory. European Journal of Economics Finance and Administrative Science, 25, 25-28.

Ting, C. C. (2011). The True Cause of Business Cycle. European Journal of Business and Economics, 4, 47-51.

Ting, C. C. (2012). Market Value of the Firm, Market Value of Equity, Return Rate on Capital and the Optimal Capital Structure. International Journal of Financial Research, 3, 1-6. https://doi.org/10.5430/ijfr.v3n4p1

Ting, C. C. (2017a). Quantity Theory of Money: True or False. International Journal of Economics and Finance, 9(10). https://doi.org/10.5539/ijef.v9n10p46

Ting, C. C. (2017b). Price Rigidity and Wage Rigidity: Market Efficiency or Market Failure. International Journal of Economics and Finance, 9(11). https://doi.org/10.5539/ijef.v9n11p82

Williamson, S. (2015). The Phillips Curve after the Great Recession. The fred blog, Federal Reserve Bank St. Louis. Retrieved from https://Fredblog.stlouis.org/2015/11

\section{Copyrights}

Copyright for this article is retained by the author(s), with first publication rights granted to the journal.

This is an open-access article distributed under the terms and conditions of the Creative Commons Attribution license (http://creativecommons.org/licenses/by/4.0/). 